\title{
ZE STUDIÓW NAD OBRZĄDKIEM POGRZEBOWYM SPOLECZNOŚCI KULTURY WIELBARSKIEJ NA POJEZIERZU GNIEŹNIEŃSKIM. PRZYKLAD CMENTARZYSKA W PALĘDZIU KOŚCIELNYM (STAN. 1) W POWIECIE MOGILEŃSKIM ${ }^{1}$
}

\author{
ON THE FUNERARY RITES OF THE POPULATION \\ OF THE WIELBARK CULTURE IN THE GNIEZNO \\ LAKE DISTRICT. A CEMETERY IN PALĘDZIE KOŚCIELNE \\ (SITE 1), MOGILNO DISTRICT
}

\author{
Andrzej Smaruj \\ Muzeum Archeologiczne w Biskupinie \\ ul. Kolejowa 25, 88-420 Rogowo, Polska \\ a.smaruj@wp.pl
}

\begin{abstract}
This paper presents the results of archaeological excavations at the burial mound cemetery used by a Wielbark culture community at Palędzie Kościelne, in the Gniezno Lake District. The sources provide further contribution to a better understanding of the funeral rites of the communities occupying north-east Wielkopolska during the Roman Iron Age.
\end{abstract}

KEY WORDS: Roman Iron Age, cemetery, burial mound, funeral riteS, Wielbark culture, Palędzie Kościelne, Gniezno Lake District

\footnotetext{
${ }^{1} \mathrm{~W}$ przygotowaniu artykułu korzystano ze sprawozdań z badań, dokumentacji rysunkowej i fotograficznej zgromadzonej w archiwum WUOZ w Bydgoszczy (teczka Palędzie Kościelne) oraz polowego dziennika badań i zabytków ruchomych będących w posiadaniu Oddziału PAN w Poznaniu. Za możliwość skorzystania z tych źródeł dziękuję kierownikom tych instytucji. Osobne podziękowanie kieruję w stronę p. mgr Joanny Sawickiej i mgr Elżbiety Dygaszewicz. Za konsultację naukową dziękuję prof. dr. hab. Henrykowi Machajewskiemu i dr. Danielowi Żychlińskiemu.
} 
Problematyka obrządku pogrzebowego ludności kultury wielbarskiej w Wielkopolsce była w ostatnich latach tematem opracowań Alicji Gałęzowskiej (2007, s. 155-234) oraz Daniela Żychlińskiego (2014). W syntezach tych został podsumowany dotychczasowy stan badań, jak również przedstawiono archeologicznie uchwytne elementy rytuału pogrzebowego. Dzięki temu ustalono pewien kanon praktyk ze sfery obrzędowości sepulkralnej ludności kultury wielbarskiej w Wielkopolsce. Nie był on rzecz jasna jednakowy na całym obszarze i z uwagi na sąsiedztwo grup kultury przeworskiej podlegał pewnym przekształceniom. Zjawisko polegające na przenikaniu pewnych elementów „przeworskich” na grunt „,wielbarski” czytelne jest m.in. na Pojezierzu Gnieźnieńskim. W jego wschodniej części, na ziemi mogileńskiej, znajduje się cmentarzysko w Palędziu Kościelnym, stan. 1. Wyniki prac archeologicznych tam prowadzonych, dotychczas jeszcze nieopracowanych, stanową cenną wskazówkę do badań nad omawianą problematyką, dlatego pozwolę sobie na przedstawienie dostępnych mi źródeł.

W 1985 r. na zlecenie Biura Badań i Dokumentacji Zabytków w Bydgoszczy (obecnie Wojewódzki Urząd Ochrony Zabytków w Toruniu Delegatura w Bydgoszczy) rozpoczęly się trwające przez 5 sezonów badania wykopaliskowe na stanowisku nr 1 w Palędziu Kościelnym. Bezpośrednią przesłanką do ich podjęcia było niszczenie obiektów archeologicznych wynikające ze stosowania głębokiej orki. Prace ukierunkowano były przede wszystkim na rozpoznanie zachowanych kurhanów, łączonych pierwotnie z okresem neolitu. Ustalenia te opierały się na podstawie częściowo rozkopanego tam w 1894 r. megalitycznego grobowca kultury amfor kulistych (Wiślański 1966, s. 162 ryc. 18; Prinke, Wiślański 1973, s. 28 tabl. 30: 1-17), oznaczonego jako kurhan $\mathrm{nr} 3$.

Badania wykopaliskowe, którymi początkowo kierowali Tadeusz Wiślański i Joanna Sawicka prowadzono w latach 1985-1987, a następnie kontynuowano w 1990 i 1993 r., przy czym T. Wiślańskiego zastąpiła mgr Elżbieta Dygaszewicz. Prace skoncentrowano na nasypach kamiennych, założono też niewielki sondaż w otoczeniu drugiego kopca. Ogółem zbadano powierzchnię 5,5 ara, rejestrując 8 grobów odpowiadających dwóm fazom użytkowania stanowiska przypadającym na okres halsztacki i okres wpływów rzymskich. W nasypach kurhanów 1 i 2 odkryto także bezkontekstowe zabytki z przełomu neolitu i epoki brązu (ryc. 8: 5-10) oraz z okresu nowożytnego (ryc. 8:4).

$\mathrm{W}$ połowie lat 90 . XX w. dokumentacja $\mathrm{z}$ badań oraz zabytki uległy rozproszeniu, co skutecznie utrudniło ich publikację. Mimo czasowego braku dostępu do części informacji, za celowe uznałem wprowadzenie wyników tamtych badań do szerszego obiegu naukowego. Stanowisko $\mathrm{nr} 1$ funkcjonowało dotąd w literaturze jedynie jako ,punkt na mapie”, do którego odwoływali się m.in. T. Makiewicz (1991, s. 279), T. Skorupka (Skorupka 2001, s. 227), A. Gałęzowska (2007, s. 197, nr 71) i D. Żychliński (Żychliński 2014, s. 53). Nierzadko informacje pojawiające się w literaturze przedmiotu były ze sobą sprzeczne, co przyczyniło się do obniżenia rangi i wiarygodności odkryć. 


\section{Fizjografia stanowiska}

Wieś Palędzie Kościelne leży na terenie gminy i powiatu Mogilno w województwie kujawsko-pomorskim. Stanowisko $n r 1^{2}$ znajduje się w okolicach Jeziora Palędzie, w odległości kilku kilometrów na zachód od Mogilna. Jest ono zlokalizowane na łagodnym północnym zboczu rozległego wzniesienia (ryc. 1) będącego elementem moreny bocznej. Pod względem fizjograficznym ziemia mogileńska znajduje się we wschodniej części Pojezierza Gnieźnieńskiego, w obrębie którego wydziela się w niektórych publikacjach Pojezierze Mogileńskie (por. Kondracki 1994, s. 93). Rzeźbę terenu ukształtowaną w trakcie poznańskiej fazy zlodowacenia Wisły cechuje skupienie dużych rynien jeziornych. Na podstawie formy terenu oraz zasięgu występowania kurhanów powierzchnię stanowiska w trakcie badan AZP oszacowano na ok 3,1 ha.

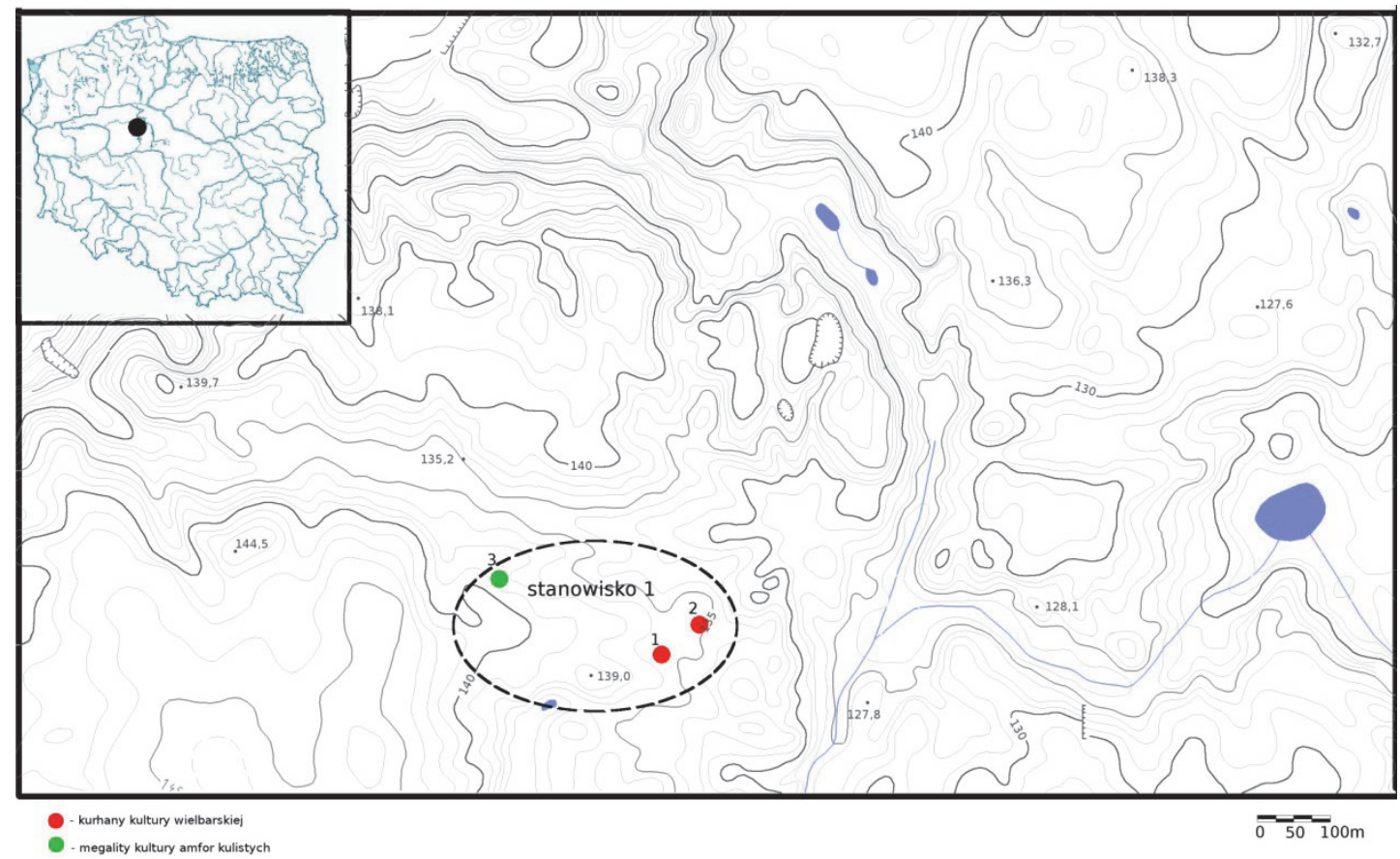

Ryc. 1. Stanowisko 1 z uwzględnieniem lokalizacji kurhanów

Fig. 1. Site 1 and the location of barrow mounds

${ }^{2} \mathrm{Z}$ uwagi na zagrożenie ze strony tzw. poszukiwaczy skarbów, w opisie położenia pominięto szczegóły ułatwiające lokalizację stanowiska. 


\section{Charakterystyka warstw i obiektów}

Obiekty znamionuje znaczny stopień zniszczenia. Niewątpliwie przyczyną takiego stanu rzeczy jest stosowanie tutaj głębokiej orki. Pojawiły się również sygnały (informacja mgr Joanny Sawickiej) o rozebraniu przy użyciu ciężkiego sprzętu przynajmniej jednego nasypu kamiennego.

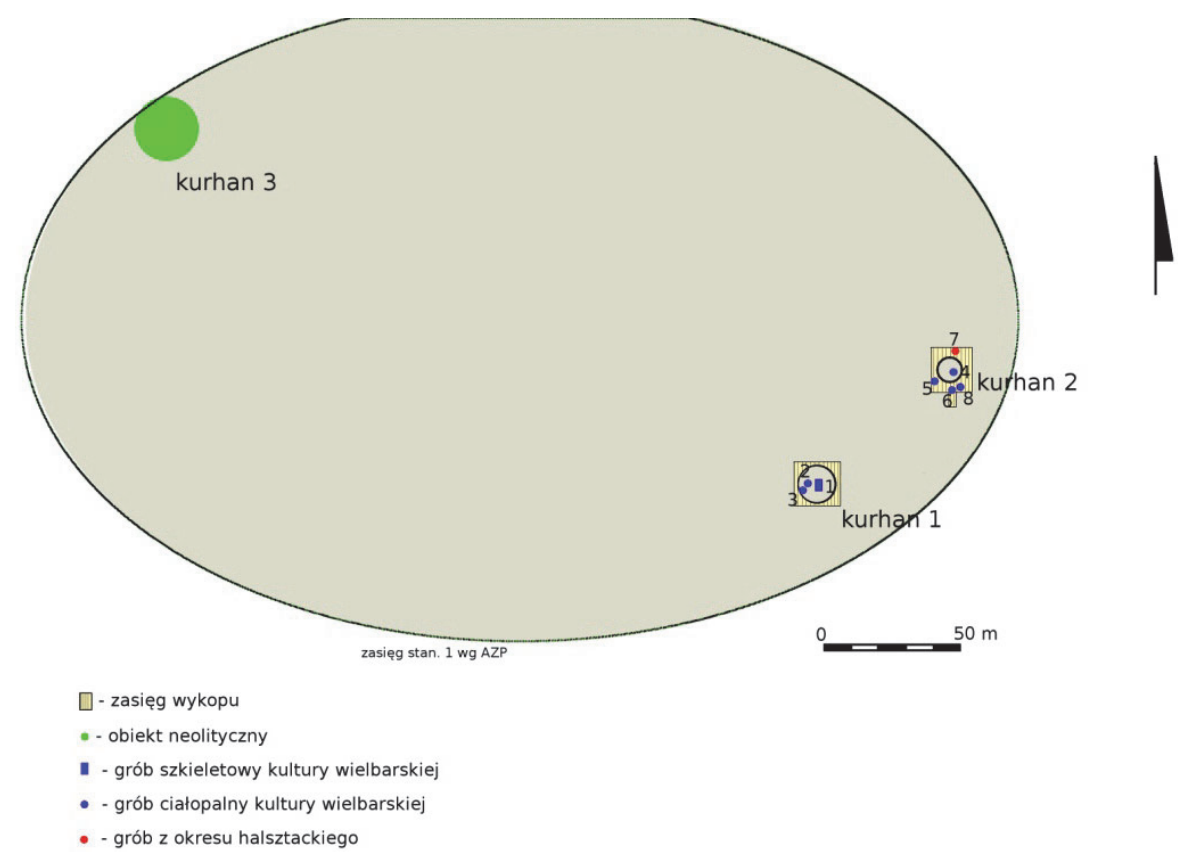

Ryc. 2. Plan stanowiska nr 1 w Palędziu Kościelnym

Fig. 2. Palędzie Kościelne, site 1. Site plan.

Destrukcyjny wpływ na stan zachowania obiektów miały również prace porządkowe polegające na oczyszczaniu powierzchni okolicznych pól z kamieni i składowaniu ich na kurhanach $\mathrm{nr} 1 \mathrm{i} 2$. W celu odtworzenia pierwotnej wielkości tych założeń sprawą podstawową stało się rozróżnienie, co jest nasypem starożytnym, a co współczesnym. Prace wykopaliskowe utrudniało też rosnące na szczycie kurhanu nr 1 drzewo oraz betonowy słup będący pozostałością po wieży triangulacyjnej niszczącej kurhan nr 2. Z uwagi na niedostępność dokumentacji, nie można w sposób pewny określić stratygrafii oraz głębokości zalegania obiektów. Dziennik badań z 1990 r. sugeruje, że groby płaskie zlokalizowane poza obrębem kurhanów występowały w calcu, bezpośrednio pod humusem. 
Przed przystąpieniem do badań kurhany podzielono na zbliżonej wielkości ćwiartki tak, że linie cięcia przebiegały na osi północ-południe i wschód-zachód. W przypadku mogiły nr 1 wytyczono metrowej szerokości świadek.

\section{KATALOG ŹRÓDEL}

Na potrzeby niniejszej publikacji zachowano numerację kurhanów przyjętą w trakcie badań, zmieniono jednak numerację grobów. Z uwagi na brak innych śladów osadnictwa, numeracja obiektów odpowiada numeracji grobów, a terminy te traktować będę zamiennie. Publikowane zabytki przechowywane są w Muzeum Archeologicznym w Biskupinie. Oznaczenia antropologiczne dwóch pochówków przyjęto za P. Banaszakiem (w tym tomie).

\section{Kurhan nr 1}

Obiekt ten znajdował się we wschodniej części stanowiska i był badany w 1985 i 1986 r. przez T. Wiślańskiego i J. Sawicką. W planie płaskim nasyp miał kształt kolisty o średnicy około $18,5 \mathrm{~m}$ i posiadał dwa kręgi kamienne: wewnętrzny o średnicy 11-12 m i oddalony od niego o około $2 \mathrm{~m}$ zewnętrzny pierścień o szerokości 2,0-2,5 m (por. ryc. 3). Niestety obydwa wieńce kamienne zostały poważnie naruszone, co uniemożliwiło precyzyjne określenie ich wielkości. Pierścień zewnętrzny, zachowany tylko we wschodniej części, zbudowany był z licowanych kamieni układanych pionowo. Wewnętrzne założenie zostało zniszczone, dlatego trudno precyzyjnie określić jego kształt i wielkość. Sam nasyp kurhanu składał się z kilku poziomów kamieni oraz warstwy ziemi. Zdaniem T. Wiślańskiego jego pierwotna średnica miała około $9 \mathrm{~m}$, a wysokość oscylowała w granicach 3-3,5 m, przy czym jego wysokość wynosi obecnie 1,1 m. Jama grobowa posadowiona była centralnie, a jej wymiary to $2,9 \times 1,9 \mathrm{~m}$. Ponadto była wkopana w calec na głębokość do $0,4 \mathrm{~m}$.

W nasypie kurhanu wydzielono cztery warstwy. Pierwszą, o miąższości około $20 \mathrm{~cm}$, tworzył współczesny humus, z niewielką ilością małych kamieni (średnicy ok 10-15 cm). Występowała ona lokalnie w północnej i zachodniej części obiektu. Druga warstwa składała się z ciemnoszarego piasku z dużą ilością kamieni, a w centralnej partii nasypu dodatkowo pojawiła się domieszka próchnicy. Możliwe że poziom ten stanowi pozostałość po pierwotnym nasypie kurhanu. Poniżej zalegała warstwa piasku przemieszanego z próchnicą i węglami drzewnymi, silnie nasycona materiałem zabytkowym. Być może stanowi ona pozostałość po obrzędach towarzyszących pogrzebowi/budowie kurhanu. Poniżej zalegała warstwa drobnoziarnistego jasnego piasku, która wyznaczała poziom pierwotnej próchnicy. Calec stanowiła pomarańczowa glina. 

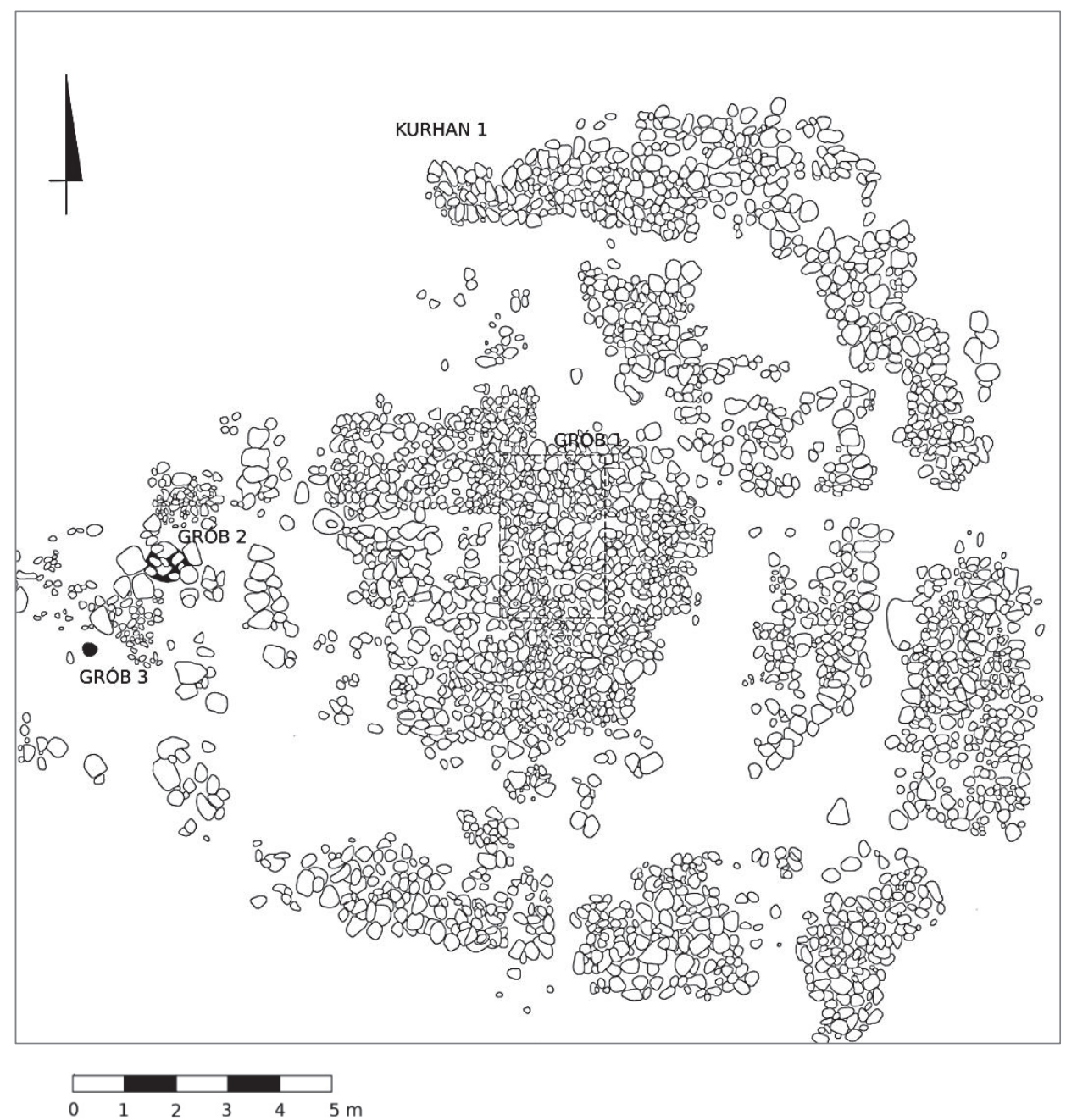

Ryc. 3. Plan płaski kurhanu 1. Oprac. A. Smaruj na podstawie dokumentacji polowej. Przybliżony zarys jamy grobowej (grób 1) wg A. Smaruj

Fig. 3. Plan of barrow mound 1. Prepared by A. Smaruj on the basis of field documentation. Approximate outline of the burial pit (grave 1), according to A. Smaruj

W centralnej części kurhanu uchwycono ślad prostokątnego w zarysie i lejowatego w przekroju wkopu rabunkowego, którego rozmiary na szczycie kopca wynosiły ok. $4,0 \times 4,0 \mathrm{~m}$, zwężając się do około $2 \times 3 \mathrm{~m}$ na poziomie calca. Jego wypełnisko jest słabo widoczne na profilu kurhanu, wyróżnia się jedynie brakiem frakcji węgli drzewnych oraz licznymi cienkimi warstewkami gliny. We wkopie zalegał kamień o wymiarach $1,40 \times 0,80 \mathrm{~m}$, będący najpewniej stellą stojącą pierwotnie na 
szczycie grobowca, oraz liczne fragmenty ceramiki określonej w dzienniku badań jako „wielbarskiej” i „przeworskiej”. Rabunku dokonano jeszcze w starożytności zapewne z dużą dokładnością, o czym świadczy zupełny brak zabytków wewnątrz komory grobowej. W trakcie doczyszczania profilu zauważono natomiast cienkie warstewki zlasowanego drewna zalegające na dnie komory grobowej, stanowiące być może pozostałości po marach (informacja ustna mgr Joanny Sawickiej). W profilu wkopu widoczne były układy wytrąconych przez wodę żyłek żelazisto-gliniastych. Na szczycie kurhanu zalegał starannie ułożony bruk kamienny. W interpretacji T. Wiślańskiego (sprawozdanie z badań za rok 1987) zasypisko wkopu rabunkowego powstało dwuetapowo. Bezpośrednio po dokonaniu rabunku wykop zasypano kamieniami i ziemią. Z biegiem czasu zasypisko „osiadło”, pozostawiając widoczne zagłębienie, które jeszcze w starożytności miało zostać wyrównane, a na jego szczycie starannie ułożono bruk kamienny. Badacz ten interpretował owe działania jako swojego rodzaju praktyki społeczno-polityczne ludności kultury przeworskiej.

W zachodniej części nasypu kurhanowego pomiędzy kamieniami znajdowały się dwa groby jamowe (nr 2 i 3), oddalone od siebie o około 1 m (por. ryc. 3).

Grób 1. Grób szkieletowy(?). Jama grobowa o wymiarach ok. 2,9 × 1,9 m znajdowała się pod kurhanem nr 1, w jego centralnej części (ryc. 3). Nie odnaleziono elementów wyposażenia i szczątków szkieletu. Przy dnie jamy grobowej zachowały się cienkie warstwy drewna - być może są to pozostałości mar. Brak oznaczenia antropologicznego.

Inwentarz: brak - obiekt wyrabowany(?)

Chronologia: okres wpływów rzymskich

Grób 2. Grób ciałopalny popielnicowy z resztkami stosu. Jama grobowa o średnicy $0,48 \mathrm{~m}$ i głębokości $0,12 \mathrm{~m}$ składała się $\mathrm{z}$ dwóch niewielkich przegłębień zalegających na różnych poziomach. W wypełnisku zadokumentowano niewielką ilość resztek stosu oraz przepalone kości ludzkie. Grób był częściowo zniszczony. Obiekt zalegał w nasypie kamiennym w zachodniej części kurhanu (por. ryc. 3, 10:5). Brak oznaczenia antropologicznego.

\section{Inwentarz:}

a) brązowa klamra do pasa typu III według Kostrzewskiego (ryc.10:4) lub XIV według Wiloch;

b) brązowa bransoleta $\mathrm{z}$ drutu grubości około $0,5 \mathrm{~cm}$ (zabytek niedostępny);

c) fragmenty ceramiki - prawdopodobnie dwóch naczyń (niedostępne).

Chronologia: faza B2 okresu wpływów rzymskich

Grób 3. Grób ciałopalny, popielnicowy(?) z resztkami stosu. Jama grobowa $\mathrm{o}$ średnicy około $0,5 \mathrm{~m}$ była położona $\mathrm{w}$ odległości około $1 \mathrm{~m}$ na południe od grobu nr 2 (ryc. 3). Miała postać płytkiego $(0,2 \mathrm{~m})$ przegłębienia, w wypełnisku którego zalegała niewielka ilość przepalonych kości ludzkich oraz węgli drzewnych. $\mathrm{W}$ otoczeniu grobu w piaszczystej warstwie pod kamieniami znajdowało się znisz- 
czone naczynie, pierwotnie ustawione dnem do góry. Grób najprawdopodobniej zniszczony. Brak oznaczenia antropologicznego.

Inwentarz: brązowa zapinka (niedostępna)

Chronologia: okres wpływów rzymskich

\section{Kurhan nr 2}

Kurhan 2 położony jest w obrębie tej samej formy terenowej - około $60 \mathrm{~m}$ na północny wschód od kurhanu 1 (ryc. 1,2). Poniższe ustalenia powstały na podstawie dziennika polowego i sprawozdania z badań za $1990 \mathrm{r}$.

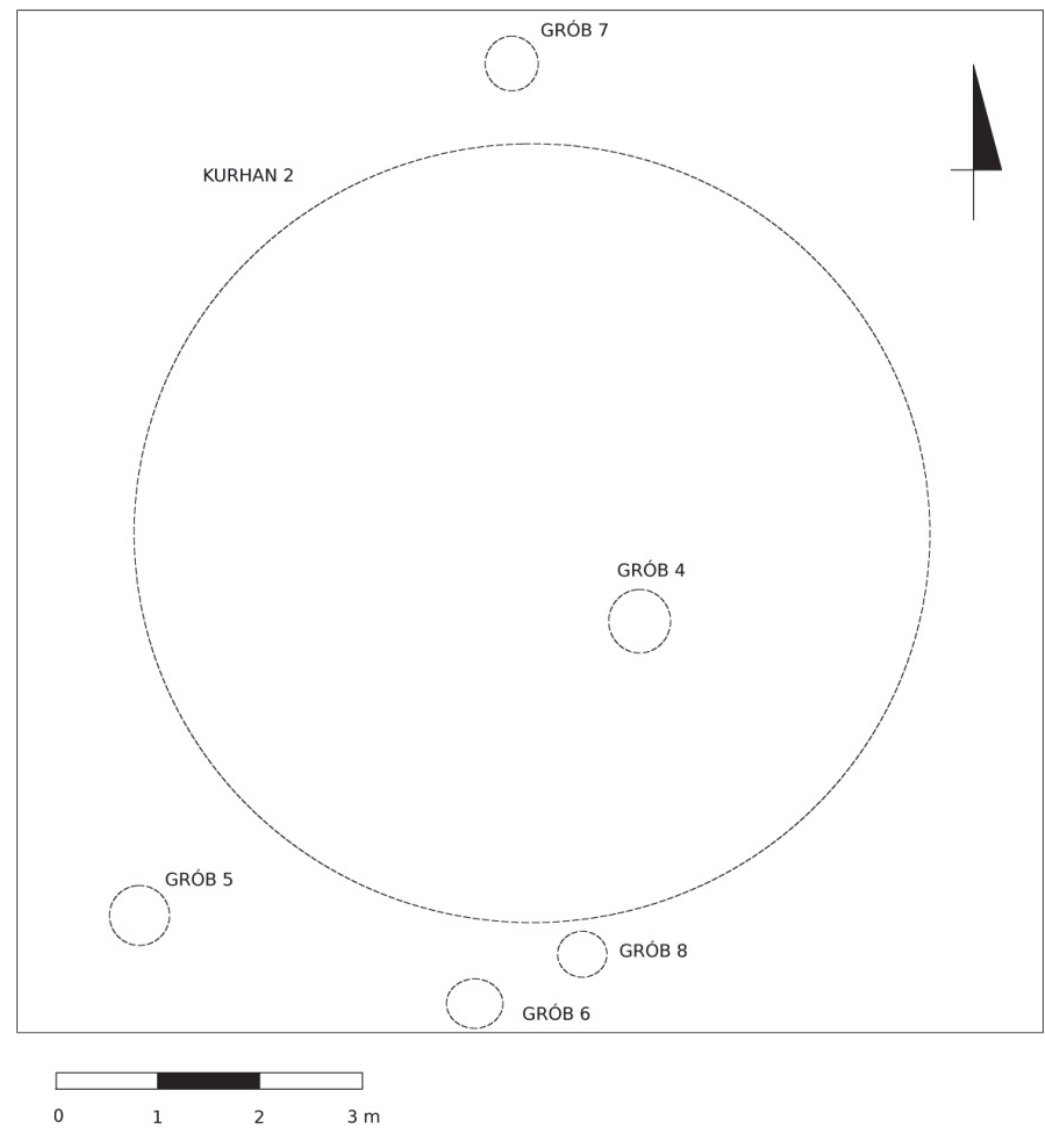

Ryc. 4. Kurhan 2 - rekonstrukcja A. Smaruj na podstawie dziennika badań. Okręgiem zaznaczono przybliżony zasięg kurhanu

Fig. 4. Barrow mound 2 - reconstruction by A. Smaruj based on the research log. The circle marks the approximate extent of the barrow mound 
Kurhan wyznaczał stosunkowo niewielki owalny nasyp kamienny o średnicy około 8-9 m, częściowo zniszczony. Zbudowany był z kilku warstw niewielkich kamieni oraz nielicznych bardzo dużych okazów leżących na obwodzie kurhanu (ryc. 7). Część z nich znalazła się w nasypie na skutek późniejszych prac agrotechnicznych. Wysokość nasypu w chwili podjęcia prac wynosiła około $1 \mathrm{~m}$. Kurhan posiadał jądro oraz wieniec kamienny zbudowany na planie koła.

Omawiana mogiła była zbudowana z trzech warstw. Pierwszy poziom to współczesny humus z dużą liczbą drobnych kamieni i nielicznymi fragmentami ceramiki. Drugi to najprawdopodobniej nasyp pierwotny kurhanu. Stanowił go ciemnożółty piasek zmieszany z niewielką ilością humusu, średniej wielości kamieniami oraz dużą liczbą ułamków ceramiki. Miejscami pojawiały się koncentracje węgli drzewnych i spalenizny, interpretowane jako paleniska. Poniżej zarejestrowano warstwę żółtego piasku drobnoziarnistego oraz występujących incydentalnie węgla drzewnego, spalenizny i gliny calcowej. Sporadycznie pojawiał się w niej też materiał zabytkowy. Być może warstwa III jest pozostałością próchnicy pierwotnej. Poniżej zadokumentowano calec - pomarańczową glinę.

Grób 4. Grób ciałopalny jamowy z resztą stosu. Jama grobowa posadowiona niecentralnie - na ćwiartce południowo-wschodniej, zalegająca $\mathrm{w}$ calcu pod nasypem kurhanu (ryc. 4). Wypełnisko stanowiły kości ludzkie z resztkami spalenizny. Brak oznaczenia antropologicznego.

\section{Inwentarz:}

a) fragment brązowej zapinki A V 124 (ryc. 11:1);

b) fragment brązowej zapinki A V s. 8, zbliżona do 128 (ryc. 11:2);

c) fragment brązowej zapinki A V s. 8, zbliżona do 128 (ryc. 11:3);

d) 16 paciorków z masy szklanej T.M. 38 (ryc. 11:4).

Chronologia: $\mathrm{B} 2 \mathrm{~b}-\mathrm{B} 2 / \mathrm{C} 1-\mathrm{C} 1 \mathrm{a}$

Grób 5. Grób ciałopalny popielnicowy. Popielnica w postaci naczynia wazowatego zdobionego pionowymi listwami była nakryta niskim garnkiem (ryc. 6). Wewnątrz urny znajdowały się przepalone kości ludzkie. Jama grobowa nieznanych rozmiarów była położona w obrębie południowo-zachodniej ćwiartki wykopu, poza wieńcem kamiennym (ryc. 4). Oznaczenie antropologiczne: kobieta? w wieku adultus.

\section{Inwentarz:}

a) brązowa jednodzielna sprzączka do pasa o ramie półkolistej $\mathrm{AD} 11$ (ryc. 12:1);

b) fragment brązowej zapinki A V s. 8 (ryc. 12:2);

c) fragment brązowej zapinki A II 41 (ryc. 12:3);

d) fragmenty szpili kościanej noszącej ślady działania wysokich temperatur (ryc. 12:4);

e) fragmenty naczynia wazowatego? (ryc. 12:5); 
f) naczynie wazowate VIA (ryc. 12:6);

g) miniaturowe naczynko z przykrywką typu XIIB (ryc. 12:7).

Chronologia: B2/C1

Grób 6. Grób ciałopalny popielnicowy. Na kamieniu skupisko przepalonych kości ludzkich oraz fragmenty przynajmniej czterech naczyń, w tym: IB, ID. Obiekt zlokalizowano w sondażu południowym, poza obrębem wieńca (ryc. 4). Grób wyraźnie zniszczony przez orkę. Oznaczenie antropologiczne: mężczyzna??? w wieku adultus/maturus.

\section{Inwentarz:}

1) naczynie gliniane - garnek typu II (ryc. 11:5);

2) naczynie gliniane nieokreślonego typu (ryc. 11:6);

3) naczynie gliniane - garnek typu IB (ryc. 11: 8);

4) fragment naczynia glinianego IC (ryc. 11:7).

Chronologia: B2-B2/C1 okresu wpływów rzymskich

Grób 7. Grób ciałopalny popielnicowy. Obiekt silnie zniszczony wskutek prac agrotechnicznych. Był zlokalizowany w północnej części wykopu, przy profilu i poza zasięgiem nasypu (ryc. 4). Sądząc po zestawie naczyń, mógł być to pochówek podkloszowy. Brak oznaczenia antropologicznego.

\section{Inwentarz:}

a) fragment talerza glinianego (ryc. 10:1);

b) fragment nieokreślonego przedmiotu kościanego (ryc. 10:2);

c) naczynie zasobowe (ryc. 10:3);

d) kilka fragmentów naczynia glinianego - garnka?

Chronologia: okres halsztacki

Grób 8. Grób ciałopalny jamowy, czysty. Skupisko kości bez wyposażenia, brak też informacji o obecności resztek stosu. Grób zlokalizowany w sondażu południowym, poza obrębem wieńca (ryc. 4). Brak oznaczenia antropologicznego.

Inwentarz: brak

Chronologia: okres wpływów rzymskich?

\section{ANALIZA MATERIALU RUCHOMEGO}

Zbiór zabytków archeologicznych pochodzących z cmentarzyska w Palędziu Kościelnym jest niejednorodny chronologicznie i kulturowo. Pod względem liczby zdecydowanie dominują znaleziska z okresu wpływów rzymskich. Znacznie rzadziej pojawiają się zabytki z przełomu neolitu i epoki brązu, okresu halsztackiego oraz czasów nowożytnych. 


\section{Neolit}

Z tym okresem łączy się kilkanaście fragmentów ceramiki, w tym 2 z zachowanym ornamentem tak zwanej rybiej ości wykonanym przy użyciu sznura (ryc. 8: 7, 10). Zdobnictwo to jest charakterystyczne dla inwentarza ceramicznego kultury amfor kulistych. Zarejestrowano je m.in. na fragmentach naczyń odkrytych w nasypach kurhanów w Strzelcach, stan. 3, pow. Mogilno (Prinke, Wiślański 1973, s. 38-39, tabl. 43:11, tabl. 46:17).

Do osobnej kategorii zabytków należy zaliczyć dłuto krzemienne (ryc. 8:5), które znaleziono w nasypie kurhanu 1. Narzędzie to, o długości $7 \mathrm{~cm}$ i szerokości 2,1 cm, wykonano z krzemienia bałtyckiego. Posiada ono bardzo bliską analogię w postaci dłuta krzemiennego z grobu w kurhanie nr 3 w Palędziu Kościelnym (Prinke, Wiślański 1973, s. 28, tabl. 30:9 - jako Padniewo stan. 1).

\section{Okres halsztacki}

O użytkowaniu cmentarzyska w początkach epoki żelaza świadczą znaleziska w postaci ceramiki z nasypu kurhanu 2 oraz znajdującego się w pobliżu grobu 7. Zespół grobowy zawierał przynajmniej 3 zniszczone naczynia, w tym talerz, garnek(?) oraz szerokootworowe naczynie zasobowe (ryc. 10:3), a także fragment przedmiotu kościanego (ryc. 10:2). Ta ostatnia forma ceramiczna miała wysokość $28 \mathrm{~cm}$ i maksymalną szerokość brzuśca dochodzącą do $42 \mathrm{~cm}$. Poza szyjką powierzchnia naczynia jest w całości chropowacona. Elementem datującym są fragmenty talerza krążkowatego (ryc. 10:1), który na Kujawach występuje od V okresu epoki brązu po okres halsztacki (Głogowski, Ignaczak 2004, s. 382).

Okres halsztacki jest także czytelny w materiale „luźnym” w postaci fragmentów naczyń zdobionych rzędem głębokich okrągłych dołków umieszczanych poniżej wylewu (ryc. 8:2,3). Podobny wątek zaobserwowano m.in. na ceramice w obiekcie nr 806 z Brześcia Kujawskiego, powiat włocławski, stan. 3 (Grygiel 1995, s. 338, ryc. 11-13) oraz Rzadkwinie, powiat mogileński, stan. 21 (Głogowski, Ignaczak 2004, s. 382) . Element ten w jest zasadniczo obcy na Kujawach i w grupie wschodniowielkopolskiej, a jego pojawienie się w tej strefie uważa się za przejaw kontaktów miejscowych społeczności z ludnością grupy tarnobrzeskiej kultury łużyckiej, gdzie podobny ornament jest często spotykany. Kolejnym znaleziskiem, które łączy się z okresem halsztackim jest ułamek naczynia $\mathrm{z}$ wątkiem $\mathrm{w}$ postaci płytkich dołków umieszczonych w układzie krokwiowym (ryc. 8:1). Wykonano je narzędziem kościanym lub patykiem w górnej partii brzuśca. Zdobnictwo to uznaje się za naśladownictwo tzw. ornamentu pseudosznurowego, wykonywanego za pomocą naszyjnika ze skręconego drutu. Podobna kompozycja pojawiła się także w jamie $1 \mathrm{w}$ Zło- 
topolu, powiat lipnowski, stan. 2 (Sobczyk 1995, ryc. 8b), Rzodkwinie, stan. 21 (Głogowski, Ignaczak 2004, ryc. 201:7) i ob. 806 w Brześciu Kujawskim, stan. 3 (Grygiel 1995, s. 348). Obiekty te datowane są na okres halsztacki D oraz odpowiadają najstarszym fazom kultury grobów kloszowych na Kujawach i tak też datuje się znaleziska z Palędzia Kościelnego. Przynależność kulturowa, z racji występowania obu rodzajów ornamentu na stanowiskach „pomorsko-kloszowych”, jak i „łużyckich" pozostaje nieustalona.

\section{Okres wpływów rzymskich}

Ceramika

\section{Formy naczyń}

W zgromadzonym materiale zabytkowym zdecydowanie dominują fragmenty naczyń ceramicznych. Zbiór ten jest zazwyczaj rozdrobniony, bez elementów dystynktywnych, co znacząco utrudnia określenie jego chronologii. Spośród zrekonstruowanych form naczyniowych 9 sklasyfikowano typologicznie $-5 \mathrm{z}$ nich pochodziło z grobów, pozostałe zalegały w otoczeniu oraz nasypie kurhanu 2. Ceramikę sklasyfikowano według schematu wypracowanego przez Ryszarda Wołągiewicza (1993).

Naczynia duże. Największe naczynia gliniane należały do grupy I, II i V. Typ I odmiany B reprezentowało naczynie o wysokości $20,5 \mathrm{~cm}$, esowatym profilu, wyodrębnionym wylewie i chropowaconej powierzchni brzuśca (ryc. 11:8). Formy te datuje się na fazy B1 - B2/C1, sporadycznie też na fazę D. Omawiany egzemplarz zdeponowany był $\mathrm{w}$ grobie 6 , wspólnie $\mathrm{z}$ fragmentami naczynia typu IC. Był to okaz o nieznanej wysokości, esowatym profilu i wyodrębnionym wylewie wychylonym nieznacznie na zewnątrz (ryc. 11:7). Ten sam typ naczynia zachowany fragmentarycznie odkryto w nasypie kurhanu 2 (ryc. 9:9). Chronologia tych mieści się w ramach faz B2 i B2/C1, choć sporadycznie pojawiały się one w całym okresie wpływów rzymskich. W grobie 6 natrafiono na naczynie o wysokości $21 \mathrm{~cm}$ i takiej samej średnicy wylewu (ryc. 11:5). Charakteryzował je esowaty profil i nieznacznie wyodrębniony, wychylony na zewnątrz wylew oraz chropowata powierzchnia brzuśca. Ze względu na ślady obecności ucha, zaliczono je do garnków uchatych typu II, występujących w fazie B2/C1 i rzadziej w przedziale B1-C1b/C2. Kolejna grupa reprezentowana jest we fragmentach pochodzących z nasypu kurhanu 2. Na ich przynależność do grupy V (II:5) wskazuje wyraźnie zaznaczony załom brzuśca oraz czarna i wyświecona powierzchnia zdobiona ornamentem rytym w postaci szachownicy. Situle są charakterystyczne dla faz B2 i B2/C1. Ostatnim z tej serii jest datowane na B2/C1 naczynie misowate odpowiadające typowi VIA (ryc. 13). W grobie 5 


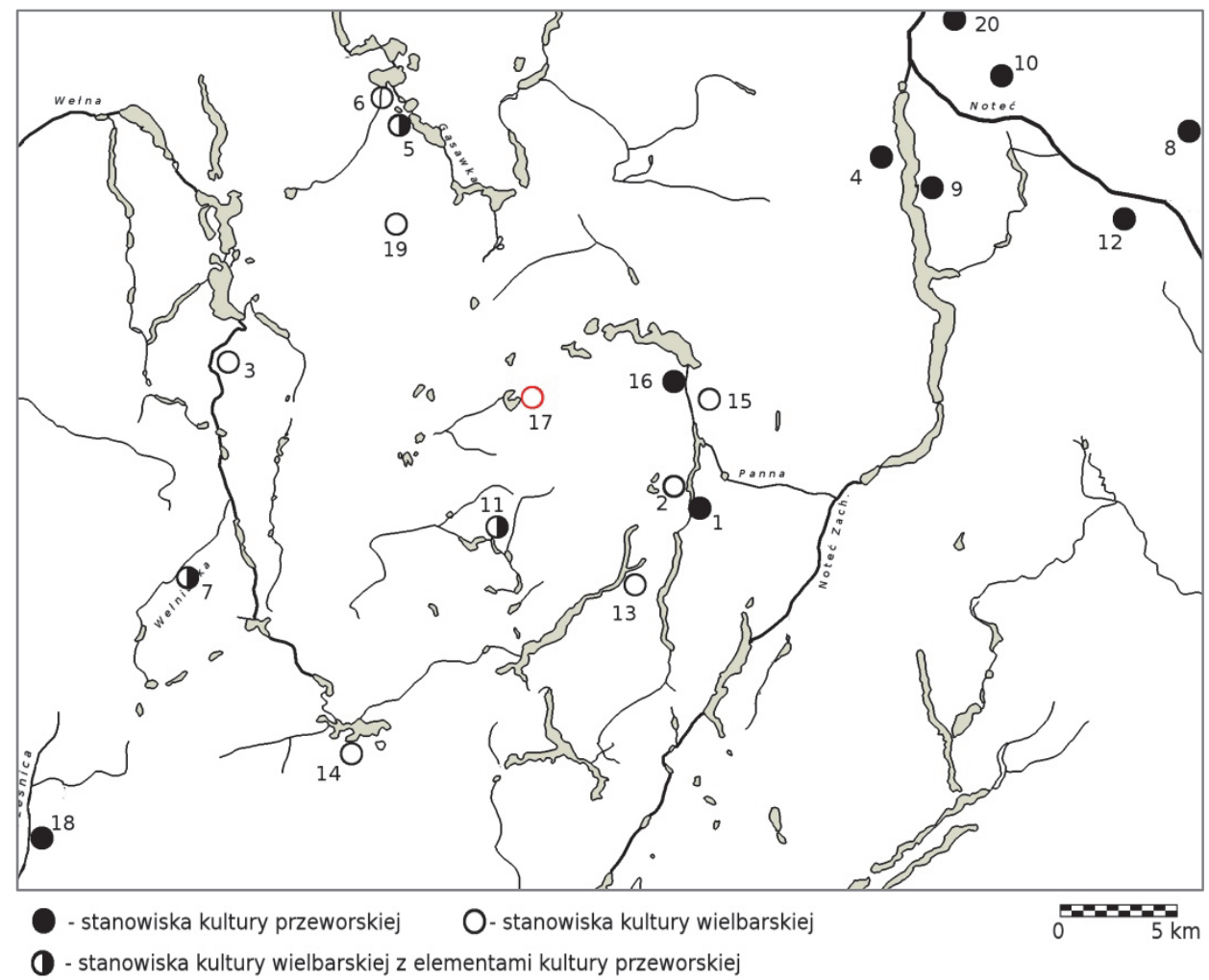

Ryc. 5. Sytuacja kulturowa w międzyrzeczu Górnej Wełny i Noteci Zachodniej. Zestawienie badanych wykopaliskowo stanowisk z okresu wpływów rzymskich

Fig. 5. Cultural situation between the Górna Wełna and Noteć Zachodnia Rivers. The map showing excavated Roman Iron Age sites

pełniło ono funkcję nakrycia popielnicy. Jest to forma szerokootworowa o wysokości $15 \mathrm{~cm}$ i średnicy wylewu 19,5 cm. Charakteryzuje się gładką powierzchnią, esowatym profilem i wylewem wyodrębnionym i wychylonym nieznacznie na zewnątrz.

Naczynia średnie. Tę grupę ceramiki reprezentują jedynie fragmenty należące do formy misowatej typu XaA odkryte w nasypie kurhanu 2 (ryc. 9:8). Omawiany okaz charakteryzował się gładką powierzchnią, wyodrębnionym dnem i wyraźnie zwężającym się ku górze wylewem. Naczynia tego typu użytkowana była w fazie B2b i B2/C1.

Naczynia male. W grobie 5 odkryto kompletnie zachowane naczynie miniaturowe wyposażone w pokrywkę (ryc. 12:7). Jest to forma wysokości 7,5 cm, ostroprofilowana, dwustożkowata, o szorstkiej powierzchni zewnętrznej barwy ceglastej. Ze względu na zbliżoną średnicę dna i wylewu można je zaklasyfikować do typu XIIB, występującego na przestrzeni całego okresu wpływów rzymskich. 


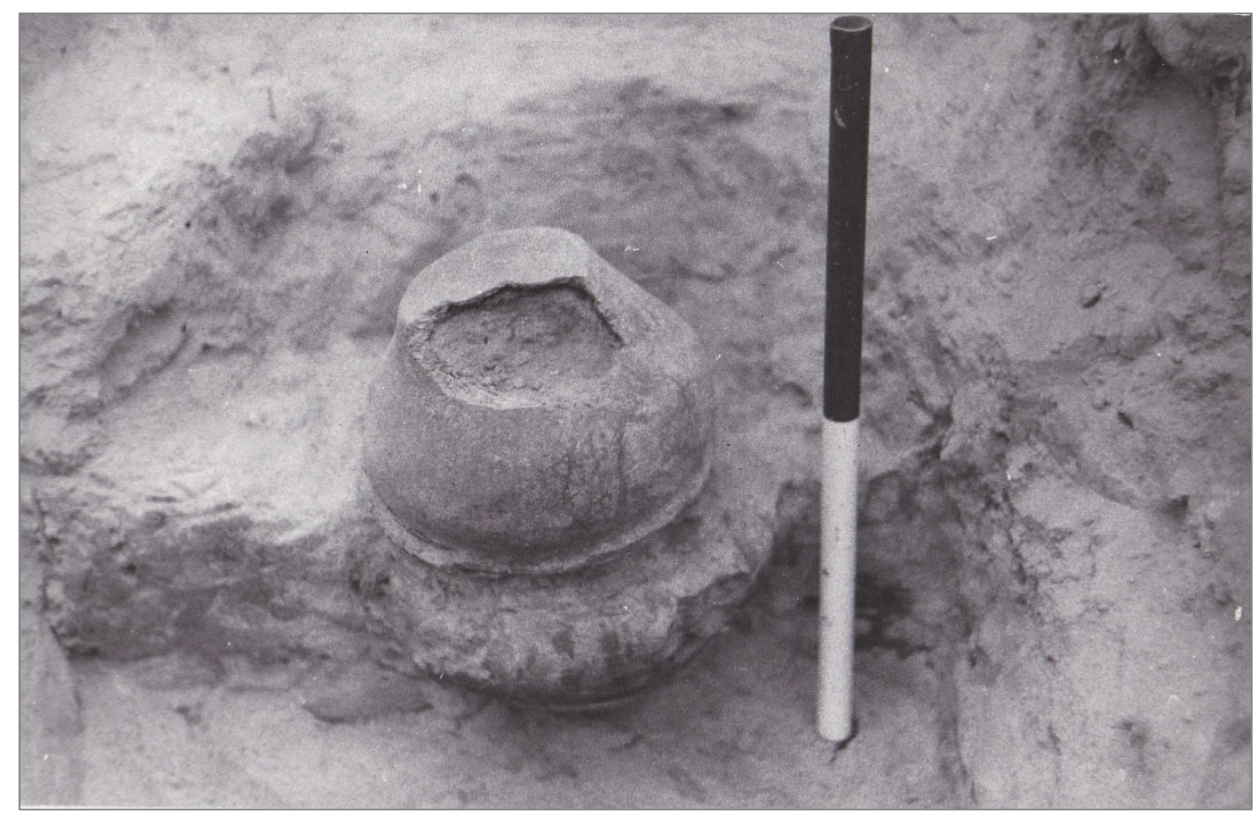

Ryc. 6. Grób nr 5 (fot. J. Sawicka)

Fig. 6. Grave 5 (photo J. Sawicka)

\section{Ornamentyka}

Elementy zdobnicze odnotowano jedynie na fragmentach dwóch naczyń. Pierwszy pochodził z nasypu kurhanu 2, kolejne odkryto w grobie nr 5 .

W pierwszym przypadku był to ornament ryty, tak zwanej szachownicy o polach pustych i ukośnie zakreskowanych, z przerywnikiem w postaci linii pionowych (ryc. 9:5). Był on umiejscowiony powyżej załomu brzuśca. Wyżej, w górnej części brzuśca znajdowały się dwie dookolne listwy plastyczne. Podobna kompozycja wątków wystąiła na wazie z cmentarzyska datowanego na I w. n.e. z Mogilna, powiat mogileński (Kostrzewski 1955, s. 235), oraz na naczyniu grupy IV z fazy B2/C1 z Kowalewka, powiat obornicki (Skorupka 2001, tabl. 144), choć tam pola szachownicy zakreskowano pionowo i poziomo.

Na częściowo zachowanej wazie z grobu 5 pojawiło się zdobienie w postaci pionowych fałd (ryc. 12:5a). Element ten miał około $3 \mathrm{~cm}$ długości i $0,8 \mathrm{~cm}$ szerokości, a znajdował się na największej wydętości brzuśca. Ze względu na stan zachowania naczynia nie sposób ustalić, czy fałdy umieszczono równomiernie dookoła całego naczynia, czy grupowano je w mniejszych koncentracjach. Mimo usilnych starań nie znalazłem podobnego wątku zdobniczego na naczyniach kultury wielbarskiej. 


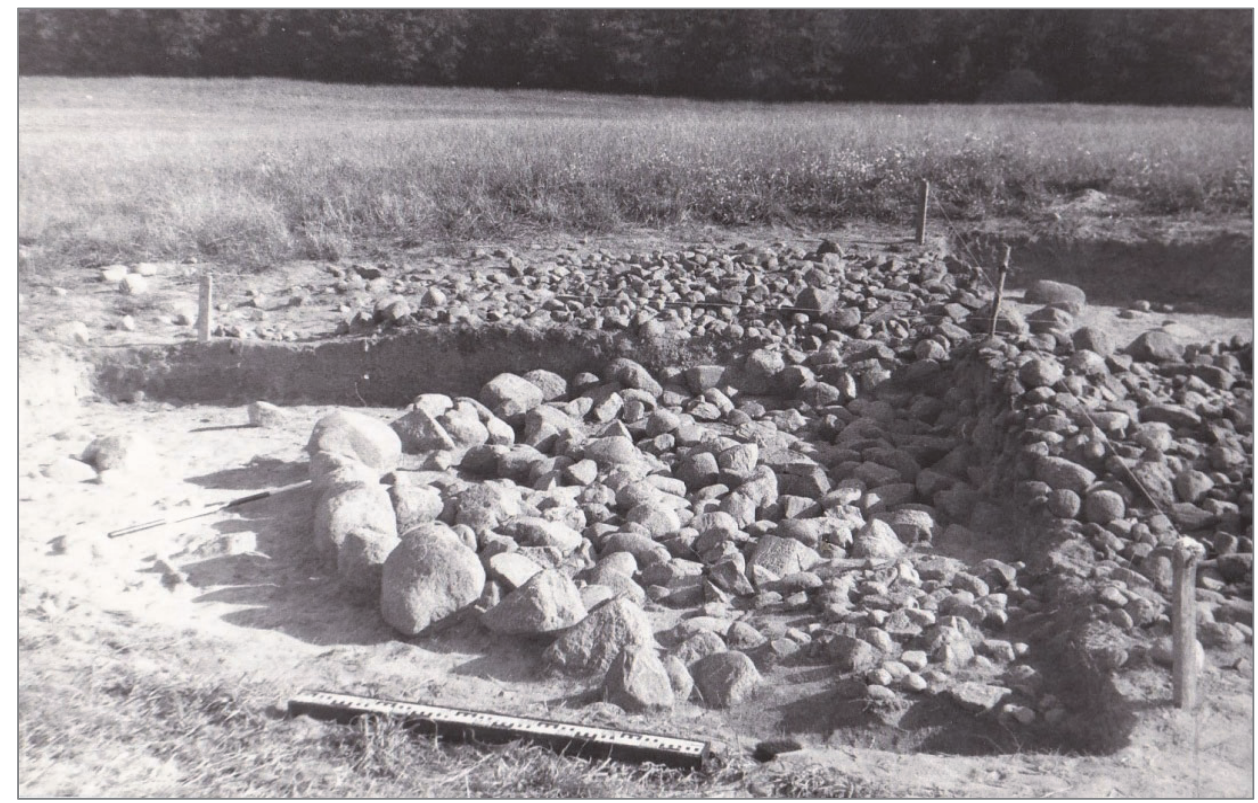

Ryc. 7. Kamienna konstrukcja kurhanu 2 (fot. J. Sawicka)

Fig. 7. A stone construction of barrow mound 2 (photo J. Sawicka)

Ozdoby i części stroju

Najliczniejszą grupą zabytków metalowych w Palędziu Kościelnym były brązowe fibule. Znaleziska te wystąpiły w grobach 2, 4 i 5 . Niestety część z była dla mnie niedostępna, dlatego ich opis opiera się na informacjach zawartych w karcie AZP. W celu zaszeregowania tej grupy zabytków, opierałem się na schemacie wypracowanym przez O. Almrena (1923) z uzupełnieniami H. Machajewskiego (1998, s. 187-196) i J. Schustera (2006, s. 101-120).

Grupę II reprezentuje zapinka typu A II 41 (ryc. 12:3) znaleziona w grobie 5. Jest to egzemplarz o długości $4 \mathrm{~cm}$, z grzebykiem osadzonym pośrodku kabłąka. $\mathrm{Na}$ podstawie formy tego elementu należy ją przypisać do wariantu X1 według Schustera (2006, s. 105-107). Fibule te są powszechnie spotykane na teranie północnej Wielkopolski - wystąpiły m.in. na nekropoliach w Kowalewku w grobie nr 239, Stołpanowie, pow. Szamotuły - grób nr 10 i Kruchowie, pow. Gniezno. Na obszarze kultury wielbarskiej wytwory te występują w fazie B2/C1 i sporadycznie w C1a.

Do grupy V Almgrena zaliczono 4 egzemplarze należące do serii 8. Pierwszy $\mathrm{z}$ nich wystąpił w grobie 5 (ryc. 12:2). Jest to forma o długości $3,8 \mathrm{~cm}$ z zachowaną sprężynką oraz grzebykiem osadzonym na główce. Dalsza część uległa nadtopieniu, co uniemożliwia bardziej szczegółowe zaszeregowanie. Zachowane cechy dystynktywne oraz niewielkie rozmiary każą zaliczyć ją do wczesnych odmian serii 8, dato- 


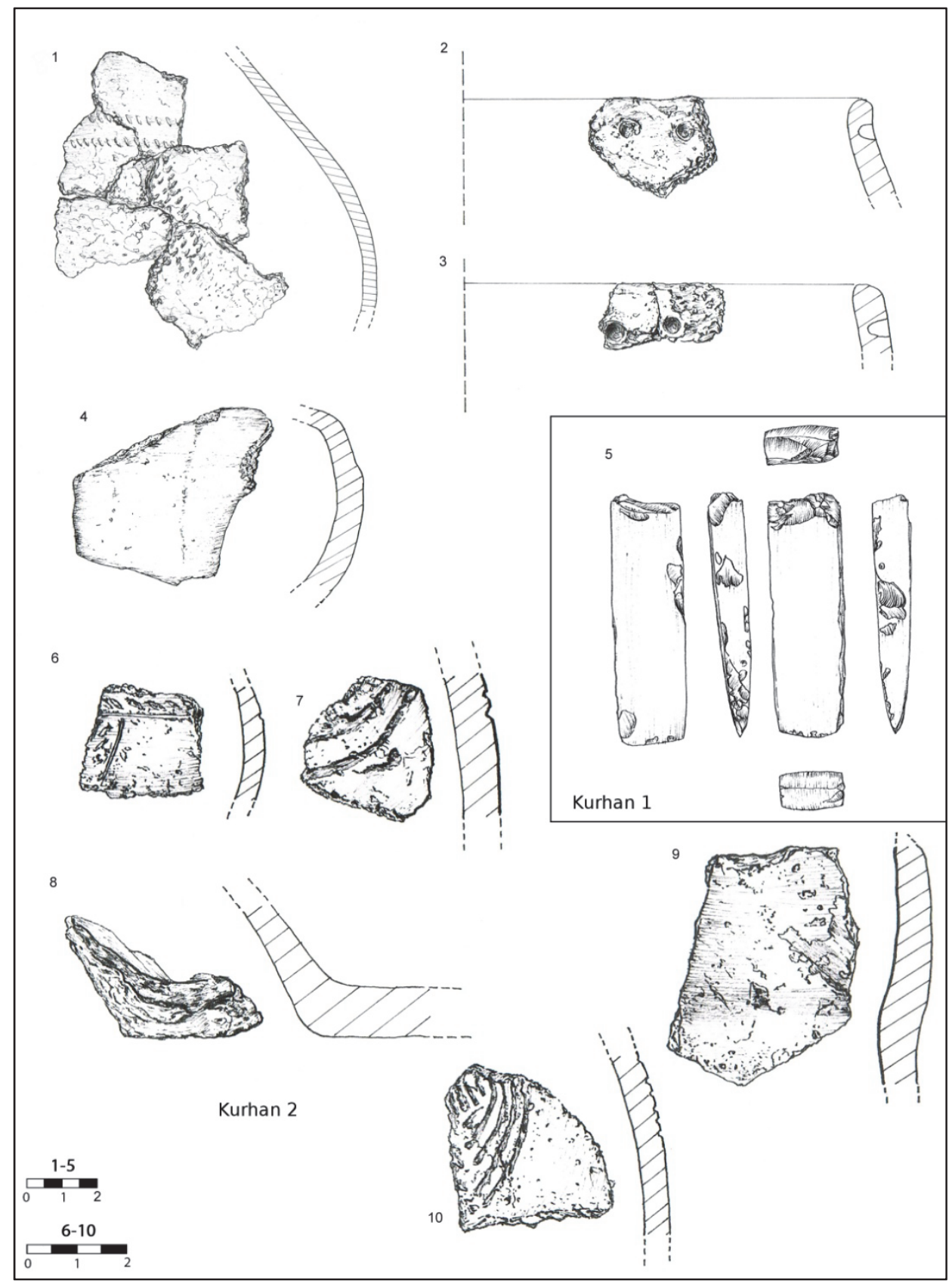

Ryc. 8. Palędzie Kościelne, stan. 1. Znaleziska luźne z nasypów kurhanu 1(5) i kurhanu 2 (1-4, 6-10). 1-4, 6-10 glina, 5 - krzemień. Rys. J. Bańkowska

Fig. 8. Palędzie Kościelne, site 1. Stray finds from the mounds of barrow 1 (5) and barrow $2(1-4,6-10)$. 1-4, 6-10 clay, 5 - flint. Drawn by J. Bańkowska 


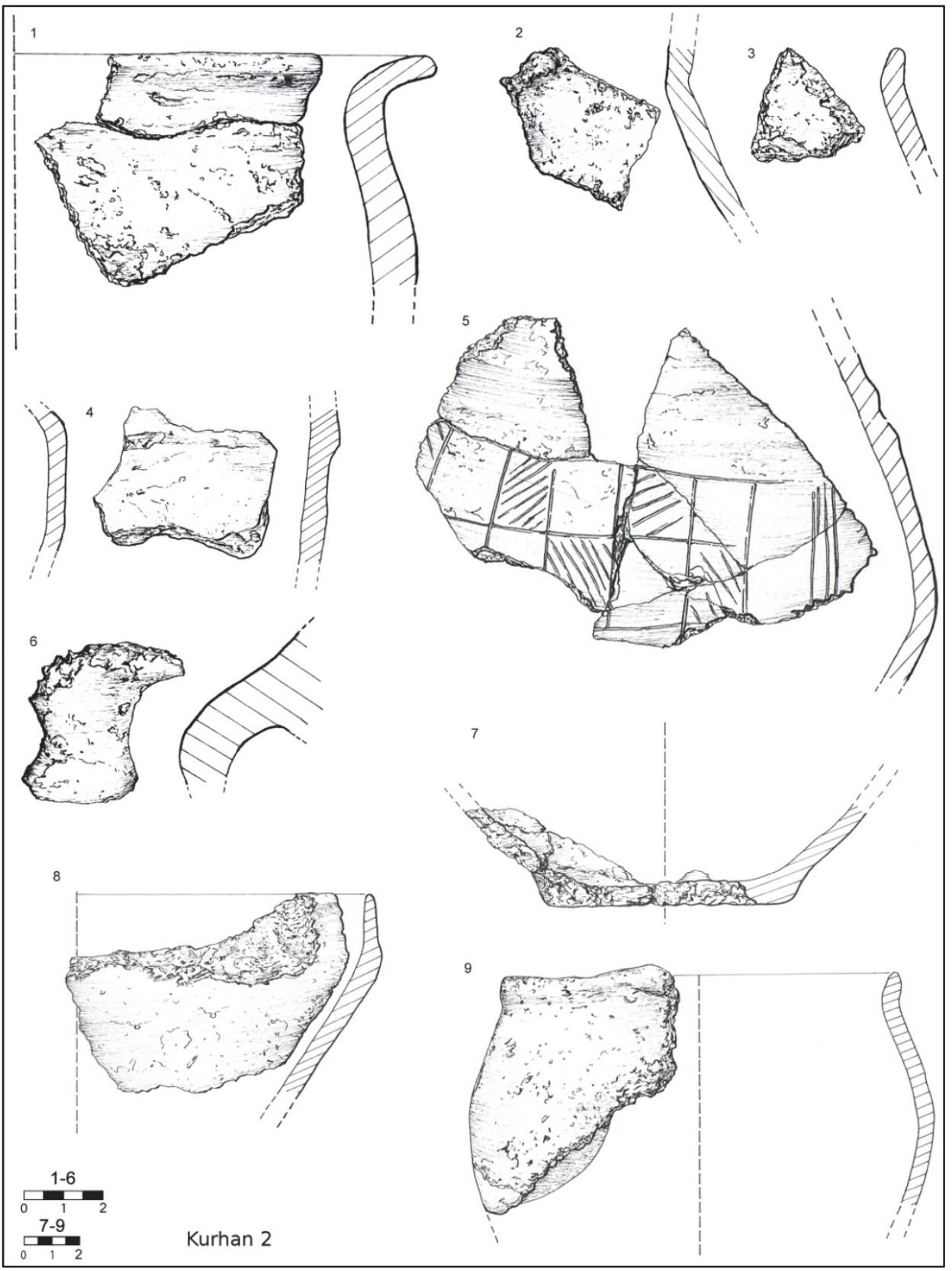

Ryc. 9. Palędzie Kościelne, stan. 1. Znaleziska luźne z nasypu kurhanu 2. 1-9 glina. Rys. J. Bańkowska Fig. 9. Palędzie Kościelne, site 1. Stray finds from the mound of barrow 2. 1-9 - clay. Drawn by J. Bańkowska 
wanych w przedziale B2-B2/C1 (Machajewski 1998, s. 192). Kolejne zapinki tej serii pojawiły $\mathrm{w}$ grobie 4 . Były to kabłąki trzech, niewielkich rozmiarów fibul: pierwsza z rozszerzoną trapezowatą nóżką i grzebykiem zdobionym techniką granulacji zbliżona do typu A V 124 (ryc. 11:1), druga z szerokim kabłąkiem i nieznacznie wyodrębnionym szerokim grzebykiem, co pozwala ją przypisać do typu A V 128 (ryc. 11:2). Analogicznie prezentuje się trzeci zabytek, który wyróżnia się zachowanymi na grzebyku pozostałościami srebrnej folii (ryc. 11:3). Zapinki te występują od fazy B2b do fazy C1b (Machajewski 1998, s. 192).

$\mathrm{W}$ grobie 1 znaleziono zagięte $\mathrm{w}$ połowie dłuższe ramię brązowej klamry do pasa (ryc. 10:4). Forma ta w zachowanej części miała długość $30 \mathrm{~cm}$ i szerokość od 2,6 do $5,7 \mathrm{~cm}$. Klamra miała dwa otwory oraz trójkątne w przekroju żeberko szerokości $1 \mathrm{~cm}$ i wysokości $0,8 \mathrm{~cm}$. Zabytek zachował się w stanie dobrym, z ubytkiem w okolicach szerszego końca oraz drugim w połowie długości. Znalezisko to nawiązuje do typu III według J. Kostrzewskiego. Podobne klamry występują powszechnie w kulturze oksywskiej (Bokiniec 2008, s. 74-75), gdzie ich liczba tylko na ziemi chełmińskiej szacowana jest na 40 egzemplarzy. Brązowe klamry do pasa użytkowane były przez cały młodszy okres przedrzymski, a największa liczba tego typu znalezisk przypada na fazę A1b-A2. Sporadycznie występują one także w inwentarzu kultury wielbarskiej, gdzie „przeżywają się” aż po fazę B1 (np. grób 280 z cmentarzyska w Lubowidzu, por. Wołągiewicz 1995, s. 34; Wiloch 1995, s. 24), jednak z uwagi na brak innych źródeł umożliwiających tak wczesne datowanie znaleziska z Palędzia Kościelnego należałoby ją umieścić raczej w ramach fazy B2a.

Do elementów zapięcia pasa należy również znaleziona $\mathrm{w}$ grobie 6 brązowa sprzączka (ryc. 12:1). Jest to egzemplarz płaski w przekroju, konstrukcji jednodzielnej i o półokrągłej ramie, odpowiadający typowi AD 11 według R. Matydy-Legutko (1978). Forma ta należy do szeroko rozpowszechnionych w kulturze wielbarskiej, także na obszarach Wielkopolski. Podobne okazy pochodzą m.in. z cmentarzysk w Kowalewku (Skorupka 2001, s. 143) i Zakrzewskiej Osadzie, pow. sępoleński (Losiowie 2013, s. 35, grób 86), gdzie datuje się je od fazy B2b po fazę C1b, przy czym najliczniej pojawiają się w zespołach z fazy B2/C1.

Wśród pozostałych zabytków znajduje się egzemplarz szpili z grobu 5, wykonany z kości lub poroża, zachowany w kilku fragmentach (ryc. 12:4). Jest to okaz szablasto wygięty o zachowanej długości $8 \mathrm{~cm}$, z główką profilowaną na kształt nakładających się na siebie pierścieni. Zabytek nie ma ścisłego odpowiednika w kulturze wielbarskiej, gdzie szpile wykonane z materiałów organicznych występują z niewielką częstotliwością. Ich chronologia zamyka się w przedziale od fazy B2b po okres późnorzymski, przy czym najliczniej występują w fazie B2/C1 (TempelmannMączyńska 1989, s. 65-77). Podobne zabytki spotyka się w kulturze przeworskiej, gdzie znalezisko z Palędzia Kościelnego odpowiada typowi VIIIB według schematu A. Dulkiewicz (2009, s. 231). Analogicznych dziewięć okazów odkryto na stanowiskach kultury przeworskiej w materiałach mieszczących się w przedziale od fazy B1 po fazę B2/C1. 


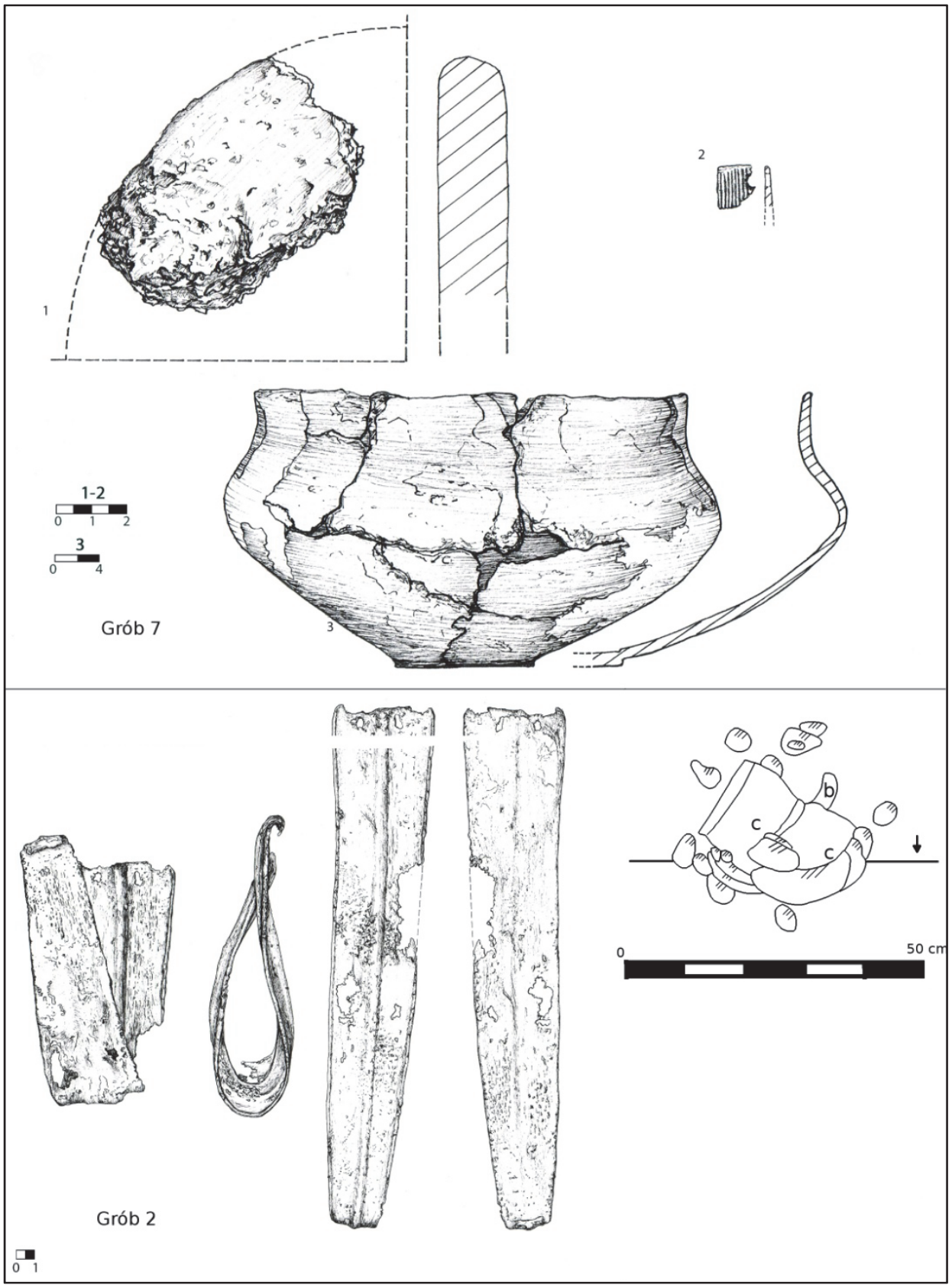

Ryc. 10. Palędzie Kościelne, stan. 1. Grób 7: 1,3 - glina, 2 - kość; grób 2: 1 - brąz. Rys. J. Bańkowska Fig. 10. Palędzie Kościelne, site 1. Grave 7: 1, 3 - clay, 2 - bone; grave 2: 1 - bronze. Drawn by J. Bańkowska 
W trakcie eksploracji grobu 4 pozyskano 16 egzemplarzy paciorków wykonanych z pomarańczowej masy szklanej (ryc. 11:4). Były to płaskie paciorki o średnicy do $0,6 \mathrm{~cm}$. Wszystkie należały do grupy II według M. Tempelmann-Mączyńskiej (1985) i można je datować na fazę B2/C1.

\section{CECHY OBRZĄDKU POGRZEBOWEGO}

\section{Okres halsztacki}

Na podstawie dostępnych danych rozpoznanie zwyczajów pogrzebowych społeczności użytkującej cmentarzysko w początkach epoki żelaza jest bardzo utrudnione. Nieustalona pozostaje rzecz tak podstawowa, jak choćby forma grobu, choć zestaw darów grobowych, w tym szerokootworowego naczynia zasobowego sugeruje, że możemy mieć do czynienia ze zniszczonym grobem podkloszowym.

\section{Okres wpływów rzymskich}

Cmentarzysko funkcjonujące w okresie wpływów rzymskich znamionował birytualizm, przy czym obrządek szkieletowy pojawił się tylko w jednym przypadku, mianowicie w obiekcie nr 1. Jama grobowa pozbawiona była, co prawda, kości i wyposażenia, lecz na podstawie jej rozmiarów i zarysu można określić, że zmarłego pochowano na osi północ-południe. Wśród 5 pochówków ciałopalnych trzy (ob. 3, 5, 6) określono jako popielicowe, przy czym wobec niedostępności dokumentacji w ten sposób potraktowano wszystkie groby wyposażone w naczynia. Dalsze dwa obiekty (nr 4 i 8) zawierały przepalone kości złożone w jamie zapewne w pojemnikach organicznych. Groby popielnicowe, poza jednym (ob. 3), nie zawierały resztek stosu. Być może praktyka ta dotyczyła większej liczby pochówków, jednak wobec zaginięcia materiałów kostnych sugestie te nie mogą zostać potwierdzone. Obecność szczątków „,czystych” jest w kulturze wielbarskiej rzeczą często spotykaną, ponieważ udział tego typu praktyk tylko na nekropoliach wielkopolskich widoczny jest w przypadku około 30\% grobów (Żychliński 2007, s. 520, ryc. 11).

Stanowisko w Palędziu Kościelnym zwraca uwagę głównie z racji współwystępowania kurhanów i grobów płaskich. Ich wzajemne relacje wymagają komentarza, jednak z uwagi na stan rozpoznania i niedostępność części dokumentacji, możliwości odczytania reguł, którymi kierowały się grupy użytkujące to miejsce, są znacznie ograniczone. Zapewne kurhany pełniły funkcję organizującą przestrzeń cmentarzyska. Czytelne jest to szczególnie w przypadku mogiły $\mathrm{nr}$ 2, gdzie groby płaskie lokowano dookoła nasypu. W przypadku kurhanu 1 dwa groby znajdowały się w nasypie, lecz i tu braki dokumentacji nie pozwalają na rozpoznanie relacji stratygraficznych. 


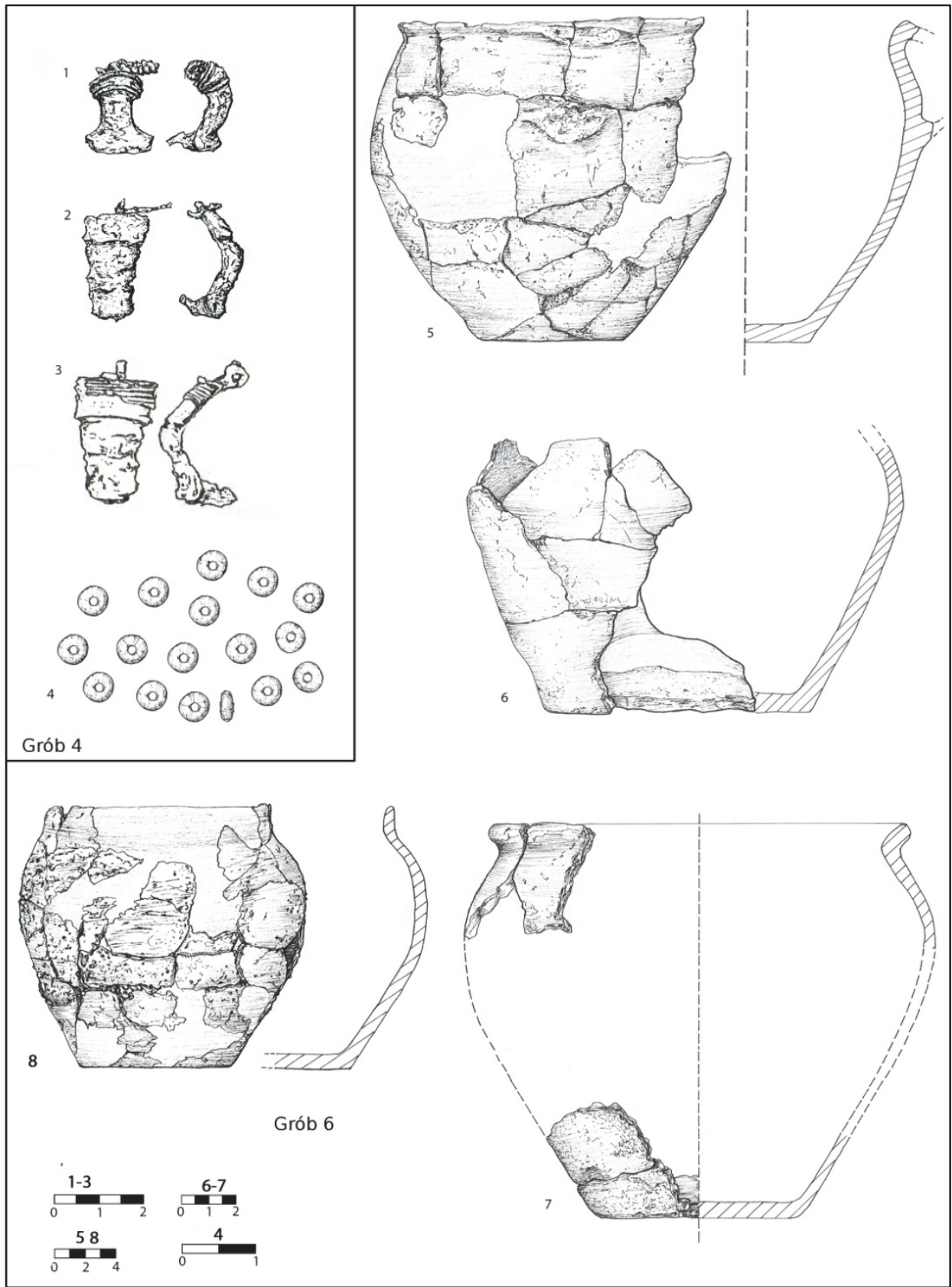

Ryc. 11. Palędzie Kościelne, stan. 1. Grób 4: 1-3 - brąz, 4 - masa szklana; grób 6: 5-8 - glina. Rys. J. Bańkowska

Fig. 11. Palędzie Kościelne, site 1. Grave 4: 1-3- bronze, 4 - glass; grave 6: 5-8 - clay. Drawn by J. Bańkowska 


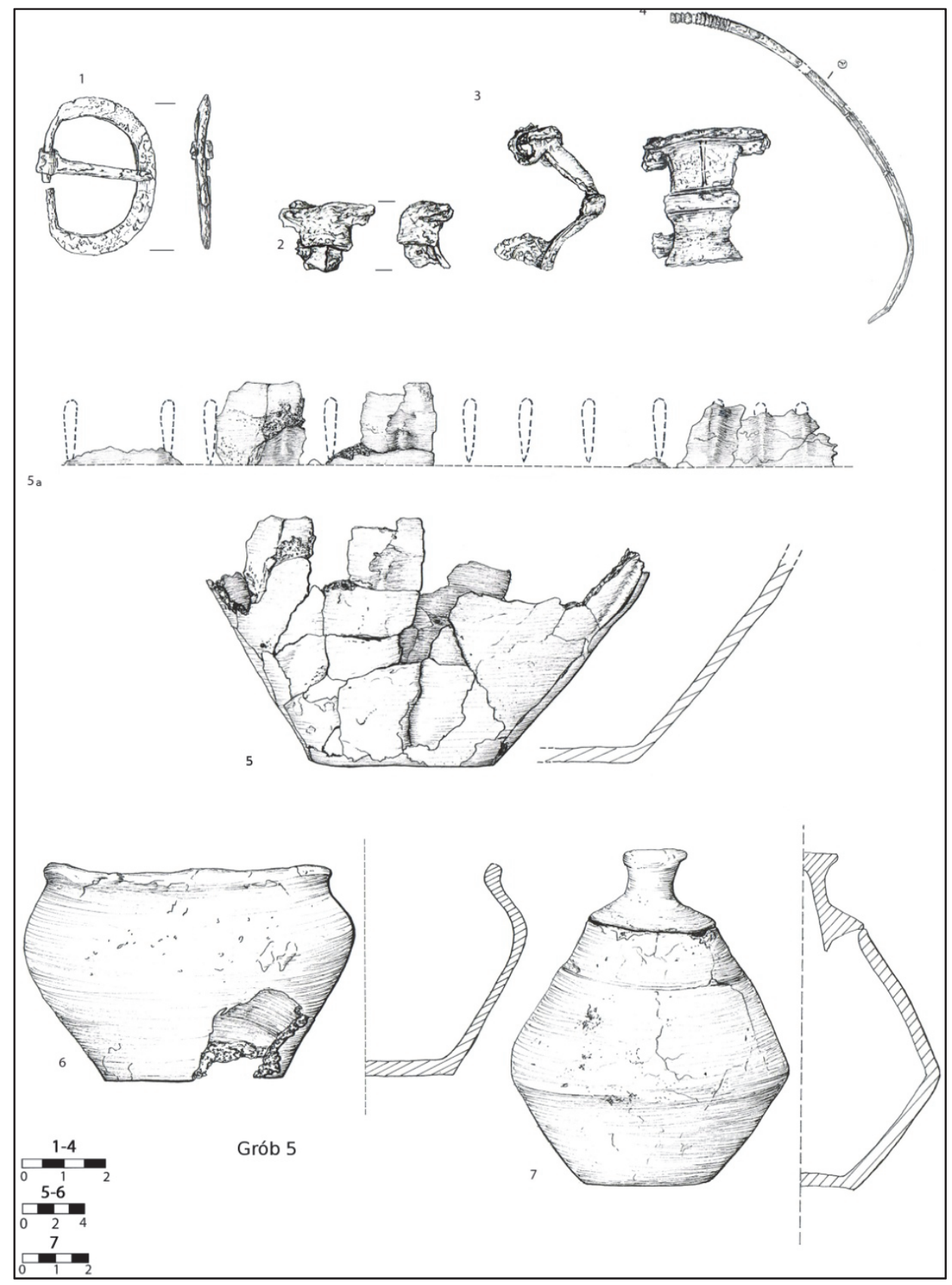

Ryc. 12. Palędzie Kościelne, stan. 1. Grób 5: 1-3 brąz, 4 - kość, 5-7 glina. Rys. J. Bańkowska Fig. 12. Palędzie Kościelne, site 1. Grave 5: 1-3 bronze, $4-$ bone, 5-7 clay. Drawn by J. Bańkowska 
$-$

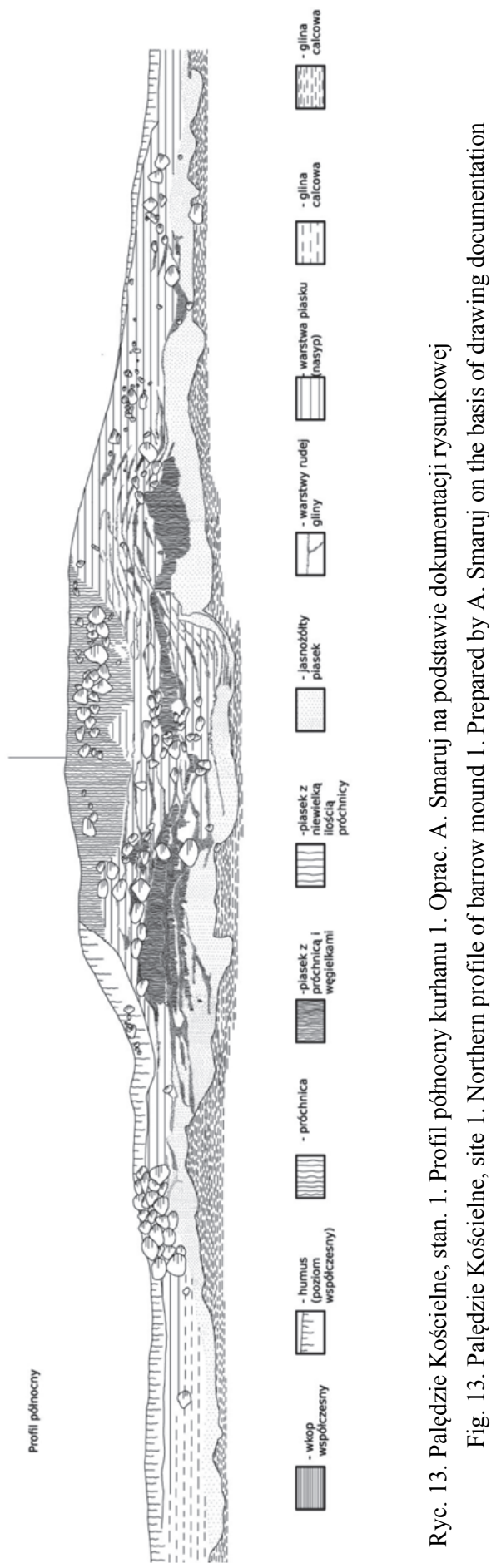


Wyposażenie odkrytych grobów było mało zróżnicowane. Dominują w nim ozdoby z brązu i ceramika, przy zupełnym braku wyrobów z metali szlachetnych oraz przedmiotów importowanych. Elementy stroju wystąpiły w trzech (obiekty $\mathrm{nr} 3,4,5$ ), a ceramika - nie licząc popielnic - w dwóch grobach (obiekty $\mathrm{nr} 5 \mathrm{i}$ 6). Zarówno przedmioty brązowe, jak i szpila kościana noszą ślady działania wysokich temperatur, co sugeruje ich obecność na stosie pogrzebowym lub w jego otoczeniu. Na uwagę zasługuje także celowo zniszczona brązowa klamra do pasa z grobu 2. Zwyczaj takiego sposobu postępowania $\mathrm{z}$ wyposażeniem grobowym jest całkowicie niespotykany na cmentarzyskach ludności kultury wielbarskiej w Wielkopolsce. Nie dotyczy to natomiast społeczności kultury przeworskiej, gdzie rytualne niszczenie wyposażenia grobowego było chętniej praktykowane. Warto jednak zaznaczyć, że i w tym ugrupowaniu celowe uszkadzanie elementów stroju zdarzało się znacznie rzadziej niż w przypadku innych kategorii przedmiotów (Żychliński 2014, s. 156).

Interesującym zjawiskiem jest kwestia przenikania niektórych obyczajów ludności kultury przeworskiej do obrządku pogrzebowego ludności użytkującej cmentarzysko. Za takie uważa się odwracanie popielnic do góry dnem, jak również przykrywanie ich innymi naczyniami. Za inspiracje ze strony ludności „przeworskiej” można uznać duży ( 3 z 7 pochówków) udział grobów ciałopalnych z resztkami stosu - odmiany sporadycznie występującej na nekropoliach „wielbarskich” (Żychliński 2007, s. 521), a także obecność szpili kościanej i celowo zniszczonej klamry do pasa.

\section{CHRONOLOGIA CMENTARZYSKA}

Na podstawie dostępnych analizie zabytków ustalono, że cmentarzysko użytkowane było w trzech okresach. Nieliczne znaleziska neolityczne należy synchronizować $\mathrm{z}$ kurhanem $\mathrm{nr}$ 3, datowanym na starszą fazę kultury amfor kulistych. Ich obecność w nasypach obu kurhanów jest zapewne wynikiem procesów podepozycyjnych i należy je uznać za przypadkowe.

Dalszą grupę materiałów w postaci ułamków naczyń glinianych z nasypu kurhanu 2 oraz wyposażenia grobu 7 zaklasyfikowano do okresu halsztackiego i najstarszych faz kultury pomorskiej. Ustalenia te opierają się na analogii do znalezisk z Brześcia Kujawskiego stan. 3 (Grygiel 1995, s. 319-358) i Rzodkwina, stan. 21 (Głogowski, Ignaczak 2004, s. 373-391).

Apogeum użytkowania omawianej nekropolii przypada na fazę $\mathrm{B} 2 / \mathrm{C} 1$, choć można również przyjąc szersze ramy od fazy B2b po fazę C1a okresu wpływów rzymskich. Taką chronologię oparto na podstawie wyposażenia dwóch grobów płaskich i pojedynczego, który znajduje się pod kurhanem $\mathrm{nr} 2$. Same mogiły są zapewne najstarszymi obiektami, które „organizowały” przestrzeń sepulkralną. Ich obecność na stanowisku raczej nie pozostaje bez związku z megalitem kultury amfor 
kulistych. Z uwagi na niewielki stopień rozpoznania stanowiska, ograniczony w zasadzie do najbliższego otoczenia kurhanów, nieznana pozostaje pierwotna wielkość i organizacja cmentarzyska.

\section{CMENTARZYSKO W PALĘDZIU KOŚCIELNYM A OBLICZE KULTUROWE ZIEMI MOGILEŃSKIEJ W OKRESIE WPLYWÓW RZYMSKICH}

Nekropolia ludności kultury wielbarskiej prezentuje dużą wartość poznawczą. Społeczności te, w przedziale od fazy B1b i B2 po C1b i C2 objęły swoim osadnictwem rozległe tereny północnej Wielkopolski, mniej więcej po linię MogilnoGniezno-Poznań-Grodzisk Wlkp. (Skorupka, Strzyżewski 2006, s. 108; Żychliński 2014, s. 62, mapa 8). Prezentowane cmentarzysko użytkowane było w okresie jej najintensywniejszego rozwoju przypadającego na początki późnego okresu wpływów rzymskich. Ziemia mogileńska pełniła wówczas rolę strefy przejściowej, na której stykały się grupy społeczne i wpływy kultury wielbarskiej i przeworskiej zasiedlającej Kujawy (ryc. 5). O ile źródła dotyczące osadnictwa drugiej z kultur są efektem nowszych badań, przez co są dobrze udokumentowane, o tyle znaleziska dotyczące kultury wielbarskiej pochodzą przeważnie z końca XIX i początków XX w. i należą w większości do znalezisk bezkontekstowych. Kulturę wielbarską reprezentują cmentarzyska w Kruchowie gm. Trzemeszno z fazy B2b-B2/C1-C1a (por. Machajewski 1980, s. 53, ryc. 6; Gałęzowska 2007, s. 193 nr 47), Krzyżownicy gm. Mogilno z fazy B2/C1 i Mogilnie stan. BN (Gałęzowska 2007, s. 193 nr 50, s. 197 nr 64). $Z$ osadnictwem przeworskim łączą się cmentarzysko i osada ludności tej kultury z fazy B2/C1 z Mogilna, stan. 22 (Bednarczyk, Sujecka 2004), oraz osiedla ludności kultury przeworskiej z wczesnego okresu wpływów rzymskich w Chabsku, stan. 41. Stanowiska te znajdują się w odległości ok. 6-8 km od siebie. Również badania powierzchniowe realizowane w ramach programu Archeologicznego Zdjęcia Polski nie przyczyniły się do poszerzenia naszego stanu wiedzy o tym terenie i wskazały niewielkie koncentracje w postaci kilku śladów i punktów osadniczych.

Cmentarzysko wielbarskie w Palędziu Kościelnym jest dopiero trzecim stanowiskiem z kurhanami położonym na południe od Noteci. Jako pierwsze było badane cmentarzysko w Łężcach, pow. czarnkowsko-trzcianecki, gdzie zarejestrowano nasyp kamienno-ziemny (Makiewicz 1988, s. 81). Dalej istnieje podejrzenie istnienia 4 kurhanów o konstrukcji ziemnej na cmentarzysku w Kowalewku (Skorupka 2001, s. 219, 226-227). Kurhany na wymienionych stanowiskach łączy znaczny stopień zniszczenia, co uprawdopodabnia spostrzeżenie Tadeusza Makiewicza, że wyższa niż na Pomorzu i Mazowszu kultura rolna przyczyniła się do zniszczenia w Wielkopolsce cmentarzysk kurhanowych z okresu wpływów rzymskich.

Wydaje się, że zmiany osadnicze w zachodniej część powiatu mogileńskiego przebiegały w sposób znamionujący całe Pojezierze Gnieźnieńskie w późnym okre- 
sie wpływów rzymskich. Obecność założeń o formie kurhanowej w strefie pogranicza wielbarsko-przeworskiego jest zjawiskiem nowym w literaturze, przez co nakazuje ponowne przeanalizowanie problemu sąsiedztwa obu ugrupowań w północnowschodniej Wielkopolsce. Postulat ten może być jednak zrealizowany dopiero na podstawie nowych źródeł, jak również opracowań stanowisk już badanych.

\section{BIBLIOGRAFIA}

Bednarczyk J., Sujecka A.

2004 Młodszy okres przedrzymski i rzymski. W: J. Bednarczyk, A. Kośko (red.), Od dhugiego domu pierwszych rolników do dworu staropolskiego. Wyniki badań archeologicznych na trasach gazociagów Mogilno-Włocławek i Mogilno-Wydartowo (s. 399-454). Poznań:

Bokiniec E. Wydawnictwo Poznańskie.

2008 Kultura oksywska na ziemi chetmińskiej w świetle materiałów sepulkralnych. Torun: Muzeum Okręgowe w Toruniu.

Dulkiewicz A.

2009 Szpile rogowe i kościane kultury przeworskiej na terenie Polski: typologia, chronologia i rozmieszczenie. Folia Praehistorica Posnaniensia, 15, 209-235.

Gałęzowska A.

2007 Obrządek pogrzebowy kultury wielbarskiej w Wielkopolsce. Acta Universitatis Lodziensis, Folia Archeologica, 25, s. 155-234.

Głogowski Z., Ignaczak M.

2004 Kultura łużycka. W: J. Bednarczyk, A. Kośko (red.), Od dlugiego domu pierwszych rolników do dworu staropolskiego. Wyniki badań archeologicznych na trasach gazociagów Mogilno-Włoctawek i Mogilno-Wydartowo (s. 373-397). Poznań: Wydawnictwo

Grygiel R. Poznańskie.

1995 Sytuacja kulturowa w późnym okresie halsztackim i wczesnym lateńskim w rejonie Brześcia Kujawskiego. W: T. Węgrzynowicz i in. (red.), Kultura pomorska i grobów kloszowych. Razem czy osobno? (s. 319-358). Warszawa: Państwowe Muzeum Archeologiczne w Warszawie.

Makiewicz T.

1991 Wyniki badań kurhanu kultury wielbarskiej w Łężcach na terenie północno-zachodniej

Machajewski H.

Wielkopolski. Sprawozdania Archeologiczne, 43, s. 265-279.

1980 Kultura wielbarska a kultura przeworska w Wielkopolsce. Fontes Archaeologici Posnanienes, 29, s. 49-64.

Machajewski H.

1998 Die Fibeln der Gruppe V, Serie 8, im ostlichen Teil Mitteleuropas. W: J. Kunow (red.), 100 Jahre Fibelformen nach Oscar Almgren. Internationale Arbeitstagung 25.-28 Mai 1997 in Klein Machnow, Land Brandenburg (s. 187-196). Wunstorf: Brandenburgisches Landesmuseum für Ur- und Frühgeschichte.

Kondracki J.

1994 Geografia Polski. Mezoregiony fizyczno-geograficzne. Warszawa: Wydawnictwo Naukowe PWN. 
Kostrzewski J.

1956 Wielkopolska w pradziejach (wyd. III). Warszawa - Wrocław: Zakład Imienia Ossolińskich.

Prinke A, Wiślański T.

1973 Materiały do osadnictwa w epoce kamienia na terenie powiatu mogileńskiego. Fontes Archeologici Posnanienis, 23.

Skorupka T.

2001 Cmentarzysko birytualne ludności kultury wielbarskiej (od połowy I w. n.e. do początku III w. n.e.). W: M. Chłodnicko (red.), Archeologiczne badania ratownicze wzdhuz trasy gazociagu tranzytowego (t. 2, Wielkopolska, cz. 3). Poznań: Wydawnictwo Poznańskie.

Skorupka T., Strzyżewski C.

2006 Cmentarzysko ludności kultury wielbarskiej w Imielnie, stan. 33, woj. wielkopolskie. Fontes Archaeologici Posnaniensis, 42, s. 97-124.

Schuster J.

2006 O późnych zapinkach kapturkowych (A II 41). Wiadomości Archeologiczne, 43, s. 101-120.

Szałkowska-Łoś J, Łoś J.

2013 Zakrzewska Osada. Cmentarzyska kultury pomorskiej i wielbarskiej na Pojezierzu Krajeńskim. Bydgoszcz-Pękowice: Muzeum Okręgowe im. Leona Wyczółkowskiego w Bydgoszczy, Wydawnictwo i Pracownia Archeologiczna PROFIL-ARCHEO.

Tempelmann-Mączyńska M.

1985 Die Perlen der romanischen Kaiserzeit und der fruhen Phase den Volkerwanderungzeit im mitteleuropaischen Barbaricum. Mainz am Rein: Verlag Philipp Von Zabern.

Tempelmann-Mączyńska M.

1989 Das Frauentrachtzubechor das mittel- und ost-europäischen Barbaricum in der romanischen Kaiserzeit. Kraków.

Wiloch R.

1995 Klamry do pasa kultury oksywskiej. Pomorania Antiqua, 16, s. 9-60.

Wiślański T.

1966 Kultura amfor kulistych w Polsce pótnocno-zachodniej. Wrocław: Zakład Narodowy Imienia Ossolińskich, Wydawnictwo Polskiej Akademii Nauk.

Wołągiewicz R.

1977 Kręgi kamienne w Grzybnicy. Koszalin: Muzeum Okręgowe w Koszalinie.

Wołągiewicz R.

1993 Ceramika kultury wielbarskiej między Battykiem a Morzem Czarnym. Szczecin: Muzeum Narodowe.

Wołągiewicz R.

1995 Lubowidz. Ein birituelles Graberfeld der Wielbark - Kultur aus Zeit vom Ende des 1. Jhs. v. Chr. bis zum Anfag des 3 Jhs. n. Chr. Kraków: Monumenta Archaeologica Barbarica.

Żychliński D.

2007 W kwestii wzajemnych oddziaływań obrządków pogrzebowych kultur przeworskiej i wielbarskiej w Wielkopolsce. W: M. Fudziński, H. Paner (red.), Nowe materiaty $i$ interpretacje. Stan dyskusji na temat kultury wielbarskiej (s. 513-526). Gdańsk: Muzeum Archeologiczne.

Żychliński D.

2014 Obrzadek pogrzebowy ludności kultury przeworskiej $i$ wielbarskiej $w$ Wielkopolsce. Zielona Góra - Gniezno: Wydawnictwo Fundacji Archeologicznej. 


\section{ON THE FUNERARY RITES OF THE POPULATION OF THE WIELBARK CULTURE IN THE GNIEZNO LAKE DISTRICT. A CEMETERY IN PALĘDZIE KOŚCIELNE (SITE 1), MOGILNO DISTRICT}

\section{Sum mary}

The paper seeks to examine archaeologically investigable characteristics of the funeral rites practiced by population of the Wielbark culture inhabiting the eastern part of the Gniezno Lake District. The results of excavations at the cemetery at Palędzie Kościelne, site 1, Mogilno Commune, provide the starting point the studies.

Dated to B2b-B2/C1-C1a, the site is located at the frontiers of the Wielbark settlement, barely a few or a dozen kilometres away from the sites of the Przeworsk culture. Six research seasons uncovered the area of about 6 ares, producing two stone and earth barrows and eight graves (including seven dating from the Roman Iron Age). Inside the larger barrow (no. 1) a plunder shaft was registered, which had reached the chamber of the alleged inhumation grave. Two cremation burials were dug into the mound. Placed non-centrically below barrow 2 was a cremation burial; four further burials were registered beyond the ring, including one attributable to Hallstatt D.

At first glance, the funeral rite is typical of the 'Wielbark' community. However, a detailed analysis revealed elements characteristic of the Przeworsk world, such as a large share of graves with pyre remains, the practice of covering cremation urns with other vessels, or turning them upside down. In addition, the grave goods included a bone pin and a ritually destroyed Bronze belt buckle.

In light of the current state of research, the cemetery at Palędzie Kościelne exemplifies the relations prevailing in this part of Wielkopolska in the Late Roman period. Such cross-cultural interactions have been increasingly observed both at settlement sites (Gąsawa, site 6; Goślinowo, site 3) and cemeteries (Stołpanowo, site 1, assemblage from Kruchowo). 


\title{
ANEKS
}

\section{ANALIZA ANTROPOLOGICZNA PRZEPALONYCH SZCZĄTKÓW KOSTNYCH Z CMENTARZYSKA LUDNOŚCI KULTURY WIELBARSKIEJ W PALĘDZIU KOŚCIELNYM, GM. MOGILNO, STAN. 1}

\author{
Piotr Banaszak \\ ul. Stanisława Mikołajczyka 34d, 72-100 Goleniów, Poland \\ zuber.banaszak@gmail.com
}

Analiza przeprowadzona została zgodnie z powszechnie stosowanymi metodami badań szczątków ciałopalnych na podstawie prac m.in.: J. Piontka (1976, s. 247-280; 1996, 2002, s. 95-108), J. Strzałko, A. Malinowskiego, J. Piontka (1973, s. 179-201; 1974, s. 315-326), J. Gładykowskiej-Rzeczyckiej (1974, s. 85-92). Fragmenty kostne zostały rozdzielone według przynależności do poszczególnych części szkieletu, a więc: kości czaszki, tułowia, kończyn górnych, kończyn dolnych oraz pozostałe, niedające się określić elementy szkieletu. Opisu dokonano z zachowaniem podziału na kości czaszki i szkieletu postkranialnego. Wymieniono ważniejsze fragmenty kości i w miarę możliwości dokonano ich charakterystyki.

Analizowany materiał wykazywał silne rozdrobnienie, co prawdopodobnie było skutkiem przesiewania go przez sito. Był również obklejony ziemią, co sugeruje, że nie był dokładnie oczyszczony. W trakcie analizy oddzielona została spora ilość drobnych ułamków ceramiki, elementy szpili kościanej oraz ucho naczynia glinianego.

\section{GRÓB 5}

Waga szczątków to 1265 g, stopień przepalenia silny, barwa biała z rdzawymi i brunatnymi zabarwieniami. Kości należały do jednego osobnika.

Kości czaszki. Fragment łuski kości czołowej razem z częścią lewego łuku brwiowego, brzegiem nadoczodołowym lewym i wyrostkiem jarzmowym. Nieco mniejszy fragment tej kości z brzegiem nadoczodołowym prawym. Wyrostek czołowy kości jarzmowej lewej; część trzonu razem z powierzchnią oczodołową kości jarzmowej prawej. Części skaliste kości skroniowej lewej i prawej oraz wyrostek sutkowaty prawy, a także wyrostek jarzmowy lewy. Fragment zatoki klinowej lewej razem z częścią skrzydła większego i wyrostka skrzydłowatego tej kości. Część podstawna kości potylicznej razem z prawym kłykciem potylicznym. Spory fragment prawej szczęki z wyrostkiem zębodołowym. Powierzchnia wewnętrzna trzonu żuchwy, powierzchnia zewnętrzna lewego kąta tej kości z guzowatością żwaczową oraz wyrostek dziobiasty z prawej gałęzi. Spośród zachowanych korzeni zębów rozpoznano: cztery siekacze, dwa kły, trzy przedtrzonowce, cztery trzonowce górne, trzy dolne oraz dziesięć fragmentów korzeni od zniszczonych zębów trzonowych. 97 fragmentów puszki mózgowej. Spory fragment łuski kości potylicznej razem z guzowatością potyliczną oraz dwa 
elementy lewej kości ciemieniowej. Poza wymienionymi większość fragmentów nie przekracza 3-4 cm (w najdłuższym wymiarze), a około połowa z nich oscyluje wokół jednego centymetra.

Kości szkieletu pozaczaszkowego. Stosunkowo duży fragment dolnej części trzonu kości ramiennej, w przekroju trójgraniasty, spękany i wyraźnie skręcony, długości ok. $110 \mathrm{~mm}$, w obwodzie ok. $55 \mathrm{~mm}$ oraz fragment kłykcia kości ramiennej lewej. Cztery fragmenty prawej łopatki, dwa brzegu bocznego, jeden przyśrodkowego oraz jej kąt dolny. Fragment trzonu prawej kości kulszowej razem z guzem kulszowym. Część trzonu lewej kości kulszowej z powierzchnią stawową panewki. Dwa fragmenty talerza biodrowego, jeden z grzebieniem. Lewa rzepka - niemal kompletna - zdeformowana termicznie, ze zniszczonym szczytem, szerokości $31 \mathrm{~mm}$. Dwa trzony kręgów piersiowych razem z lewymi wyrostkami poprzecznymi i powierzchniami stawowymi - najprawdopodobniej trzeci i czwarty. Trzon innego kręgu z tego odcinka oraz dwa wyrostki poprzeczne od pozostałych. Trzynaście fragmentów kręgów piersiowych, osiem z nich to częściowo bądź w całości zachowane trzony bez wyrostków, pięć to zniszczone elementy trzonów należące do co najmniej dwóch kręgów. Dwa trzony kręgów z odcinaka lędźwiowego oraz trzy wyrostki poprzeczne. Powierzchnie górne i dolne trzonów powyższych kręgów, które zachowały się w dobrym stanie nie mają wyrośli kostnych ani innych widocznych nieprawidłowości morfologicznych. 75 fragmentów żeber, różnej wielkości, od zaledwie kilku mm do $68 \mathrm{~mm}$. Trzy fragmenty głowy kości ramiennej, jednak na tyle zniszczone, że nie było możliwe dokonanie jej pomiaru. Część głowy kości udowej. Koniec dalszy lewej kości łokciowej. Głowa kości promieniowej razem z szyjką i guzowatością kości promieniowej. Niestety obwód stawowy głowy jest częściowo zniszczony, co uniemożliwia dokonanie pomiaru. Oba paliczki dalsze dużego palca stopy prawej i lewej, po dwa paliczki dalsze i środkowe dłoni. Kilkanaście fragmentów kości śródręcza. Duży fragment kości księżycowatej i podobna haczykowatej.

Poza wymienionymi elementami wśród przepalonych szczątków kostnych poddanych analizie znajdowało się jeszcze kilkaset niewielkich fragmentów wielkości od kilku do kilkunastu, sporadycznie kilkudziesięciu milimetrów, których nie można było przyporządkować do żadnego rejonu szkieletu. Były to głównie drobne ułamki blaszki kostnej i kawałki tkanki gąbczastej pochodzącej zapewne z głów kości długich bądź kości różnokształtnych.

Wśród fragmentów mózgoczaszki rozpoznano odcinki szwów czaszkowych. Jedynie fragment pochodzący najprawdopodobniej z odcinka S3 szwu strzałkowego wykazuje częściową bądź niemal całkowitą obliterację, dzięki czemu wytrzymał działanie wysokiej temperatury. Proces ten rozpoczyna się u kobiet około 25 (20) roku życia, a kończy około 34 (40). Pozostałe szwy „rozeszły się” w trakcie spalania. W odcinku C3 widoczny jest początek endokranialnej oblitercji szwu, jednak nieznaczny. Z kolei w sąsiadującym z nim fragmencie pochodzącym z odcinka SP szwu klinowo-ciemieniowego nie obserwuje się śladów zarastania. Również odcinek S4 i znajdujący sią na tym samym fragmencie kostnym L1 szwu węgłowego nie wykazują jakichkolwiek znamion obliteracji, tak samo część szwu z rejonu S1. Pozostałe niewielkie części szwów, których nie można było dokładnie przyporządkować, również nie wykazują zarastania. Biorąc pod uwagę powyższe obserwacje, można z pewną ostrożnością zaklasyfikować osobnika do kategorii wiekowej adultus?

Dzięki zachowanym elementom czaszki wykazującym dymorfizm płciowy, dokonano próby jej oceny. Części zachowanych łuków brwiowych są raczej słabo uwydatnione - ewen- 
tualnie pośrednio. Guzowatość potyliczna jest wykształcona w sposób mierny. Wyrostek sutkowaty jest mały, łuki jarzmowe delikatne. Zachowany fragment gałęzi żuchwy posiada kąt zbliżony do prostego, z kolei jego powierzchnia ukształtowana jest w sposób pośredni. Wyrostek dziobiasty jest delikatny i nieduży. Brzeg górny oczodołu jest raczej cienki i ostry, możliwe że ukształtowany w sposób pośredni. Posiadając pięć z sześciu cech czaszki branych najczęściej pod uwagę w trakcie określania płci osobników z grobów ciałopalnych, można wysunąć ostrożne wnioski. Wszystkie omówione rejony ukształtowane są w sposób charakterystyczny dla kobiet, co do niektórych istnieje wątpliwość, że w sposób pośredni, jednak żaden z nich nie ma morfologii właściwej kościom męskim. Można więc przypuszczać, że analizowane szczątki należały do kobiety?

\section{GRÓB 6}

Waga szczątków wynosi 335 g, stopień przepalenia kości jest silny, barwa biała, pojedyncze fragmenty mają szare zabarwienie. Ze względu na małą ilość kości, brak drobnych i delikatnych elementów szkieletu oraz w większości zaokrąglone (zerodowane) powierzchnie przełamów, można wnioskować, że pochówek został zniszczony. Brak śladów spalenizny na kościach sugeruje obrządek bez resztek stosu - tzw. czysty. Szczątki należały najprawdopodobniej do jednego osobnika.

Kości czaszki. 29 fragmentów sklepienia czaszki, w większości masywnych pochodzących z kości ciemieniowych i potylicznej, wielkości od 21 do $35 \mathrm{~mm}$ i grubości $5,5 \mathrm{~mm}$. Niektóre przełamy kostne są na tyle wyraźne, że widać w nich ślady po zarośniętych w dużym stopniu szwach czaszkowych, nie można jednak ustalić ich dokładnego umiejscowienia. Rozpoznano również 6 elementów puszki mózgowej z niezobliterowanymi szwami czaszkowymi, wielkości od 9 do $21 \mathrm{~mm}$. Trzy z nich można przyporządkować do szwu węgłowego.

Fragment piramidy prawej kości skroniowej. Fragment wyrostka podniebiennego z elementem zatoki szczękowej i zębodołem kła prawej szczęki oraz element wyrostka jarzmowego tej kości. Wyrostek czołowy prawej kości jarzmowej z brzegiem oczodołu. Korzeń prawego kła i część korzenia przedtrzonowca. Element prawej części trzonu żuchwy, z zębodołem pierwszego trzonowca, z kompletnie zarośniętym zębodołem po drugim trzonowcu i częściowo zarośniętym po trzecim trzonowcu.

Kości szkieletu pozaczaszkowego. 13 fragmentów żeber wielkości od 19 do $29 \mathrm{~mm}$, 43 ułamki kości długich wielkości od 15 do $51 \mathrm{~mm}$. Między innymi kości łokciowej i piszczelowej. Poza jednym niezidentyfikowanym elementem nasady kości długiej wielkości 12 na $8 \mathrm{~mm}$ nie zaobserwowano tkanki gąbczastej.

Szew potyliczny w zależności od odcinka rozpoczyna zarastanie ok. 60 roku życia, a przyporządkowane fragmenty nie rozpoczęły jeszcze obliteracji. Nie ma pewności co do odcinka szwu strzałkowego, z którego pochodzą fragmenty wykazujące niemal kompletną obliterację, można jednak stwierdzić, że był to osobnik dorosły. Analizowane szczątki kostne można zaklasyfikować do kategorii wiekowej adultus/maturus?.

Niestety wśród analizowanych szczątków nie znaleziono elementów kostnych, które są istotne przy ocenie płci. Jednak masywnie wykształcone elementy puszki mózgowej oraz fragmenty żeber mogą sugerować, że szczątki należały do mężczyzny? 


\section{BIBLIOGRAFIA}

Gładykowska-Rzeczycka J.

1974 O metodach stosowanych w badaniach materiałów kostnych z cmentarzysk ciałopalnych. W: H. Giżyńska (red.) Metody, wyniki i konsekwencje badań kości z grobów ciatopalnych (s. 85-92). Poznań: Wydawnictwo Uniwersytetu im. Adama Mickiewicza w Poznaniu.

Piontek J.

1976 Proces kremacji i jego wpływ na morfologie kości w świetle wyników badań eksperymentalnych. Archeologia Polski, 21( 2), s. 247-280.

Piontek J.

1996 Biologia populacji pradziejowych. Zarys metodyczny. Poznań: Wydawnictwo Uniwersytetu im. Adama Mickiewicza w Poznaniu.

Piontek J.

2002 Wpływ procesu kremacji na morfologię kości szkieletu ludzkiego. Wyniki badań eksperymentalnych. W: J. Wrzesiński (red.) Popiót i kości (s. 95-108). Sobótka - Wrocław: Muzeum Ślężańskie im. Stanisława Dunajewskiego w Sobótce, AKME Zdzisław Wiśniewski.

Strzałko J., Piontek J.,

1974 Wpływ spalania w warunkach zbliżonych do kremacji pradziejowych na morfologię kości, Przeglad Antropologiczny, 40(2), s. 315-326.

Strzałko J., Piontek J., Malinowski A.

1973 Teoretyczno-metodyczne podstawy badań kości z grobów ciałopalnych. Materiały i prace antropologiczne, 85, s. 179-201.

Strzałko J., Piontek J., Malinowski A.

1974 Możliwości identyfikacji szczątków ludzkich z grobów ciałopalnych w świetle wyników badań eksperymentalnych. W: H. Giżyńska (red.) Metody, wyniki i konsekwencje badan kości z grobów ciatopalnych (s. 31-42). Poznań: Wydawnictwo Uniwersytetu im. Adama Mickiewicza w Poznaniu. 